\title{
FEDERAL GOMMON LAW POWER TO REMAND A PROPERLY REMOVED CASE
}

\author{
BradFord Gram Swing $†$
}

Since the Judiciary Act of $1789,{ }^{1}$ Congress has enacted statutes that grant federal courts jurisdiction over civil actions removed from state court. ${ }^{2}$ These statutes empower federal courts to hear "Cases"3 removed from state court the subject matter of which are encompassed within Congress's limited grants of jurisdiction, usually cases "arising under" federal law or cases within diversity jurisdiction. ${ }^{4}$ According to

† B.A. 1983, Oberlin College; J.D. Candidate 1988, University of Pennsylvania.

1 Ch. 20,1 Stat. 73.

2 See 28 U.S.C. § 1441(a) (1982). This provision states:

Except as otherwise expressly provided by Act of Congress, any civil action brought in a State court of which the district courts of the United States have original jurisdiction, may be removed by the defendant or the defendants, to the district court of the United States for the district and division embracing the place where such action is pending.

Id. Without jurisdictional statutes the lower federal courts would be powerless to hear cases. Article III states: "[ $t$ ]he judicial Power of the United States, shall be vested . . . in such inferior Courts as the Congress may from time to time ordain and establish." U.S. ConST. art. III, $\S 1$. The nine categories listed in article III, $\S 2$ of the Constitution set the outer limits of federal court jurisdiction. See U.S. ConsT. art. III, $\S 2$; Hodgson v. Bowerbank, 9 U.S. (5 Cranch) 303, 303 (1809); see also Insurance Corp. of Ir. v. Compagnie des Bauxites de Guinee, 456 U.S. 694, 701 (1982) ("The character of the controversies over which federal judicial authority may extend are delineated in Art. III, § 2, cl. 1."). But see National Mut. Ins. Co. v. Tidewater Transfer Co., 337 U.S. 582, 600 (1949) (three-justice plurality holding that Congress under article I may give justiciable controversies otherwise outside of article III to federal courts, "regardless of lack of diversity of citizenship"). By defining the authority of the lower federal courts it creates, Congress may restrict jurisdiction more narrowly than does article III. See Insurance Corp. of Ir., 456 U.S. at 701 ("Jurisdiction of the lower federal courts is further limited to those subjects encompassed within a statutory grant of jurisdiction.").

3 See U.S. ConST. art. III, § 2 ("The judicial power shall extend to all Cases, in Law and Equity, arising under this Constitution, the Laws of the United States, and Treaties .....").

- See 28 U.S.C. § 1441(b) (1982). This provision states:

Any civil action of which the district courts have original jurisdiction founded on a claim or right arising under the Constitution, treaties or laws of the United States shall be removable without regard to the citizenship or residence of the parties. Any other such action shall be removable only if none of the parties in interest properly joined and served as defendants is a citizen of the state in which such action is brought.

$I d$. Since the first removal statute, see Judiciary Act of 1789 , ch. $20, \S 12,1$ Stat. 73 , 79 , statutes have provided for removal on the grounds of diversity of citizenship only to parties who were not residents of the state where the suit was brought. This restriction to nonresident defendants has appeared in every provision for diversity removal juris- 
the federal courts, removal jurisdiction can extend, just as original jurisdiction can extend, to a case that includes a state law claim closely related to a federal law claim but that otherwise is not within the court's statutory jurisdiction. ${ }^{5}$ The boundaries of statutory removal jurisdiction and judicially-defined power over cases appear not wholly congruent. This divide has caused conflict in defining the scope of federal judicial power over cases removed from state court. ${ }^{6}$

Consider, for example, a case initiated in state court that contains transactionally-related claims arising under both federal and state law and that the defendant properly removes to federal court. Section 1441(b) of the Judicial Code ${ }^{7}$ grants the district court jurisdiction over the federal law claim. Common law jurisdiction attaches to the state law claim because it and the federal law claim derive from a "common nucleus of operative fact." After removal, the court dismisses the federal law claim, and the district court judge decides that the state law claim, although still within the court's incidental jurisdiction, ${ }^{9}$ should

diction except one. The exception is the Judiciary Act of 1875 , ch. 137, 18 Stat. 470 . For the text of the 1875 statute, see infra note 156 . The Judiciary Act of 1887 , ch. 373,24 Stat. 552 , corrected by Judiciary Act of 1888, ch. 866, 25 Stat. 433, again limited removal to nonresident defendants. Therefore, with the exception of references pertaining to the $1875 \mathrm{Act}$, any reference in this Comment to a party removing a diversity case to federal court, whether to a plaintiff or to a defendant, should be understood to mean a nonresident party.

see infra notes 40-47 and accompanying text. The Supreme Court refers to such a state law claim as a "nonfederal claim": "[T]he term 'nonfederal claim' means one as to which there is no independent basis for federal jurisdiction. Conversely, a 'federal claim' means one as to which an independent basis for federal jurisdiction exists." Owen Equip. \& Erection Co. v. Kroger, 437 U.S. 365, 372 n.11 (1978). A nonfederal claim can be a state law claim between co-citizens that is closely related to a claim between diverse citizens or a state law claim that is closely related to a claim arising under federal law. See infra note 9.

- For discussion of the conflict in defining the scope of federal judicial power over cases in a court's original jurisdiction, see infra notes 31-66 and accompanying text.

728 U.S.C. $₹ 1441(b)(1982)$. For the text of the statute, see supra note 4.

8 United Mine Workers v. Gibbs, 383 U.S. 715, 725 (1966). For discussion of the statutory limits on the exercise of common law jurisdiction over state law claims, see infra notes 48-58 and accompanying text.

"This Comment will use the term "incidental" jurisdiction instead of the traditional terms "pendent" and "ancillary" jurisdiction. Using the Supreme Court's current terminology, this hypothetical state law claim is within the court's pendent jurisdiction. Pendent jurisdiction "concerns the resolution of a plaintiff's federal- and state-law claims against a single defendant in one action." Kroger, 437 U.S. at 370 . Ancillary jurisdiction, by comparison, "typically involves claims by a defending party haled into court against his will, or by another person whose rights might be irretrievably lost unless he could assert them in an ongoing action in a federal court." Id. at 376. The exercise of ancillary jurisdiction over nonfederal claims often has been upheld in situations involving impleader, cross-claims, or counterclaims. See id. at 375 . Both pendent and ancillary jurisdiction are judicial doctrines that permit a federal court to exercise jurisdiction over a party or claim normally not within the scope of federal judicial power. See Matasar, Rediscovering "One Constitutional Case": Procedural Rules 
be decided in state court. ${ }^{10}$ The statute, ${ }^{11}$ however, apparently only authorizes the judge to remand cases removed "improvidently and without jurisdiction."12 Whether the statute limits the district judge's power to

and the Rejection of the Gibbs Test for Supplemental Jurisdiction, 71 CALIF. L. REv. 1399, 1401 n.1 (1983) [hereinafter "One Constitutional Case"].

Distinctions between pendent and ancillary jurisdiction have caused confusion and criticism. See Lesnik v. Public Indus. Corp., 144 F.2d 968, 974 (2d Cir. 1944) (criticizing ancillary jurisdiction as "amorphous"). See generally Matasar, $A$ Pendent and Ancillary Jurisdiction Primer: The Scope and Limits of Supplemental Jurisdiction, 17 U.C. Davis L. REv. 103, 1053(1983) [hereinafter Jurisdiction Primer] (describing incidental, or "supplemental," jurisdiction decisions as "shrouded in mystery"). A better view is that the two doctrines describe categories of incidental jurisdiction. See id. (pendent and ancillary labels "at least at their core, describe the same thing"). See generally Note, A Closer Look at Pendent and Ancillary Jurisdiction: Toward a Theory of Incidental Jurisdiction, 95 HARV. L. REv. 1935, 1936 (1982) (defining incidental jurisdiction as the power of a federal court to "decide in one case matters that, if presented separately, would be jurisdictionally insufficient because of lack of diversity of citizenship or failure to meet the amount-in-controversy requirement"). Although the Supreme Court has not analyzed judicial power over state law claims in terms of a general incidental jurisdiction, neither has it found it "necessary to determine ... "whether there are any "principled" differences between pendent and ancillary jurisdiction . . .." Kroger, 437 U.S. at 370 n.8 (quoting Aldinger v. Howard, 427 U.S. 1, 13 (1976)). Moreover, the Court has recognized that pendent and ancillary jurisdiction are "two species of the same generic problem: Under what circumstances may a federal court hear and decide a state-law claim arising between citizens of the same State?" Id. at 370 .

${ }^{10}$ Jurisdiction over a properly removed state law claim is not lost after all federal law claims have been dismissed. See Cook v. Weber, 698 F.2d 907, 909 (7th Cir. 1983); Rotermund v. United States Steel Corp., 474 F.2d 1139, 1141 (8th Cir. 1973); Brough v. United Steel Workers of Am., AFL-CIO, 437 F.2d 748, 750 (1st Cir. 1971); Murphy v. Kodz, 351 F.2d 163, 167 (9th Cir. 1965); Brown v. Eastern States Corp., 181 F.2d 26, 28-29 (4th Cir.), cert. denied, 340 U.S. 864 (1950); 1A J. MOORE \& B. Ringle, MOORE's Federal Practice II 0.160[7] (1987).

1128 U.S.C. \& 1447(c) (1982).

12 Id. Two statutory provisions authorize remand after removal, neither of which is applicable to this case. The first states in part: "If at any time before final judgment it appears that the case was removed improvidently and without jurisdiction, the district court shall remand the case . . .." 28 U.S.C. $\S 1447$ (c) (1982). The term "improvidently" generally refers to failure of the removing party to satisfy a statutory, nonjurisdictional requirement for removal, such as the posting of a bond or removing within thirty days of the service of the initial pleading. See In re Merrimack Mut. Fire Ins. Co., 587 F.2d 642, 645-47 \& nn.3 \& 8 (5th Cir. 1978); see also Note, Remand Order Review After Thermtron Products, 1977 U. ILL. L.F. 1086, 1093 (1977) (statutory term "improvidently" refers to legally defective or untimely removal petition). The hypothetical assumes that all such requirements have been satisfied. The term "without jurisdiction" is likewise inapplicable as the case was properly removed and is within the court's jurisdiction.

The second statutory provision states:

Whenever a separate and independent claim or cause of action, which would be removable if sued upon alone, is joined with one or more otherwise non-removable claims or causes of action, the entire case may be removed and the district court may determine all issues therein, or, in its discretion, may remand all matters not otherwise within its original jurisdiction. 
remand a case that was properly removed, but that in its present posture contains only state law claims, is a question that divides the courts of appeals, ${ }^{13}$ a conflict that the Supreme Court has agreed to resolve. ${ }^{14}$

This Comment will assess two views of jurisdictional authority-one based strictly on statute, the other relying on a claim of residual power to fashion common law-that conflict in defining the power to remand a properly removed case. Part I introduces the statutory bases for removal jurisdiction and examines the expansion of its scope through the development of incidental jurisdiction. It then sets forth the conflict between a federal court's statutorily-defined power to remand cases and its common law power over incidental state law claims. Part II explores judicial power to decline vested jurisdiction, as

28 U.S.C. $\S 1441$ (c) (1982). Claims that derive from a "common nucleus of operative fact," Gibbs, 383 U.S. at 725, are not "separate and independent" for the purposes of $\S 1441$ (c). See American Fire \& Gasualty Co. v. Finn, 341 U.S. 6, 14 (1951) (holding that "where there is a single wrong to plaintiff . . . arising from an interlocked series of transactions, there is no separate and independent claim or cause of action under $\S$ 1441(c)").

Federal jurisdiction over state law claims under $\S 1441$ (c) is another example of a district court's incidental jurisdiction. See supra note 9. Along with pendent and ancillary claims, such claims are a third species of the "generic problem" that the Supreme Court identified in Kroger: "Under what circumstances may a federal court hear and decide a state-law claim arising between citizens of the same state?" Kroger, 437 U.S. at 370. State law claims under $\S 1441$ (c), however, cannot formally be classified as either pendent or ancillary. As noted above, a pendent claim as defined in Gibbs cannot be "separate and independent" from an otherwise removable claim. Nor can a state law claim that a plaintiff joins with a federally cognizable claim satisfy the Supreme Court's analysis of ancillary jurisdiction. See supra note 9. For further discussion of federal jurisdiction over state law claims under $\$ 1441(\mathrm{c})$, see infra notes 140-55 and accompanying text.

${ }^{13}$ See infra note 74.

14 See Carnegie-Mellon Univ. v. Cohill, No. 85-3619, slip op., 41 Fair Empl. Prac. Cas. (BNA) 1046 (3d Cir. Aug. 29, 1986), granting mandamus in Boyle v. Carnegie-Mellon Univ., 648 F. Supp. 1318 (W.D. Pa. 1985), vacated and reh'g granted, No. 85-3619, slip op., 41 Fair Empl. Prac. Cas. (BNA) 1888, (3d Cir. Sept. 24,1986 ), affd by an equally divided court, No. 85-3619, slip op. (3d Cir. Nov. 13, 1986) (en banc), cert. granted, $107 \mathrm{~S}$. Ct. 1283 (1987). In this case, a husband and wife brought an action in the Court of Common Pleas of Allegheny County, Pennsylvania, complaining of the husband's employment termination. They alleged causes of action against his employer under various theories of tort and contract, as well as violations of state and federal age discrimination laws. Relying on the plaintiffs' federal age discrimination claim, the defendant removed the action to federal court. After discovery disclosed that the husband had never filed an age discrimination charge with a federal or state agency, a prerequisite for suit under the Age Discrimination in Employment Act, 29 U.S.C. $\$ \S 626$ (d), 633(b) (1982), the plaintiffs moved to amend their complaint to delete the federal claim and to remand the remaining state law claims to state court. The district judge granted the motion. A panel of the Court of Appeals for the Third Circuit granted the defendant's petition for mandamus and directed the district court to vacate its remand order. The court sitting en banc, however, vacated the writ and reheard the case. By an equally divided vote, it denied the petition, providing a view in microcosm of the conflict concerning the power to remand that divides the courts of appeals. See infra note 74. 
well as issues involving the separation of powers under the Constitution. Part III examines the history of removal statutes to argue that Congress's purpose in enacting removal statutes does not limit a federal court from exercising its common law authority over incidental claims. Finally, Part IV argues that a federal court's common law authority includes the power to remand and that the justifications for incidental jurisdiction-judicial economy, efficiency, and fairness to litigants-support discretionary remand of state law claims in certain cases.

\section{The SCOpe of Removal JuRisdiction}

Determining whether a federal court has removal jurisdiction over a simple case that contains a single claim is a relatively straightforward matter. Either the case comes within the limits of article III and the accompanying jurisdictional statutes or it does not. With modern developments in procedural rules, however, the scope of cases for which removal is sought has greatly expanded. This Part examines the conflict between the statute that provides for limited removal jurisdiction and a federal court's power to hear cases removed from state court that include claims both within and without those limits.

\section{A. The Statutory Bases for Removal}

The Constitution makes no mention of removal, nor was the procedure known at common law; ${ }^{15}$ yet, statutes have provided for removal jurisdiction since Congress first established lower federal courts. ${ }^{16}$ The constitutionality of removal has long been settled. ${ }^{17}$

The Judiciary Act of $1789^{18}$ provided a right to remove to nonresident defendants in diversity actions and to a party in a land title suit who claimed title under a grant from a state other than that in which the suit was pending. ${ }^{19}$ Before the Civil War, Congress expanded re-

15 See 1A J. MoORE \& B. Ringle, supra note 10, $\int$ 0.157[1.-1]; C. WRIGHT, The Law of Federal. Courts 206 (4th ed. 1983).

${ }_{16}$ See Judiciary Act of 1789 , ch. 20, \& 12, 1 Stat. 73, 79.

17 See Tennessee v. Davis, 100 U.S. 257, 267 (1879); Railway Co. v. Whitton, 80 U.S. (13 Wall.) 270, 287-90 (1871); see also Martin v. Hunter's Lessee, 14 U.S. (1 Wheat.) 304,349 (1816) (stating that the Constitution implicitly sanctions removal).

18 Ch. 20, 1 Stat. 73.

10 Id. at $\S 12,1$ Stat. at 79 . Section 12 stipulated that civil cases could be removed before trial in state courts by a nonresident or alien defendant if the jurisdictional amount, then $\$ 500$, was satisfied. See id. Jurisdiction over land title disputes also required that a $\$ 500$ jurisdictional amount be met. This provision permitted either party to remove. See id., 1 Stat. at 80 .

The Judiciary Act of 1801, ch. $4, \S 11,2$ Stat. 89, 92, granted general federal 
moval jurisdiction, but only when needed to enforce particular federal laws. ${ }^{20}$ During the War and Reconstruction, however, Congress passed many statutes containing removal provisions, ${ }^{21}$ some of which made a federal forum available to many state court defendants who previously had not been within the scope of removal jurisdiction. ${ }^{22}$ Removal jurisdiction reached its height in 1875 with legislation that permitted removal by either plaintiffs or defendants of virtually all cases within the judicial power of article III, subject only to an amount in controversy requirement. ${ }^{23}$ Congress narrowed access to federal court in 1887 with a statute limiting the right to remove to defendants. ${ }^{24}$ The present removal statute ${ }^{26}$ is closely derived from the 1887 legislation. $^{26}$

question jurisdiction, which broadened federal court power to hear cases removed from state court. It was repealed during the Jefferson Administration. See Act of Mar. 8, 1802, ch. 8, 2 Stat. 132; S. Kutler, Judicial Power and Reconstruction PolitICS 145 (1968).

${ }_{20}$ See Nonintercourse Act of 1815 , ch. $31, \S 8,3$ Stat. 195, 198-99, reenacted by Act of Mar. 3, 1815, ch. 94, $\S 6,3$ Stat. 231, 233-34 (removal, irrespective of diversity or the amount in controversy requirement, was available "for any thing done, or omitted to be done as an officer of the customs, or for any thing done by virtue of this act ...."); Force Act of 1833, ch. 57, § 3, 4 Stat. 632, 633-34 (permitting removal of suits involving "any right, authority, or title," under any federal revenue statute).

${ }_{21}$ Congress passed twelve removal provisions during this period. See S. KuTLER, supra note 19, at 147; see, e.g., Habeas Corpus Act of 1863, ch. 81, § 5, 12 Stat. 755, 756-57 (allowing federal officers or any other person to remove cases against them for wrongs done under authority of the President or federal law, even after judgment); Act of May 11, 1866, ch. $80, \S 3,14$ Stat. 46,46 (reaffirming removal rights granted by Habeas Corpus Act of 1863 and dispensing with the requirement that defendants give surety to state courts upon removal); Act of Feb. 28, 1871, ch. 99, $\S 16,16$ Stat. 433, 438-39 (allowing anyone prosecuted in state court for acts done under the provisions of the Act to seek removal; allowing removal to be based on counsel's certification that the facts presented in the petition were true; voiding state court proceedings subsequent to removal; and establishing that any attempt to prosecute the case in state court subsequent to removal was a federal misdemeanor), repealed by Act of Feb. 8, 1894, ch. 25, 28 Stat. 36. See generally S. KuTLER, supra note 19, at 145-60 (discussing removal jurisdiction during Reconstruction).

${ }_{22}$ See, e.g., The Separable Controversy Act of 1866, ch. 288, 14 Stat. 306 (allowing an out-of-state defendant, joined with in-state defendants, to remove case from state court for "final determination of the controversy, so far as it concerns him, without the presence of the other defendants"); Prejudice or Local Influence Act of 1867, ch. 196, 14 Stat. 558 (providing for removal when defendant filed an affidavit in state court stating that he had reason and did believe he could not obtain justice in state court). For a discussion of the 1866 and 1867 Acts, see infra notes 140-52 and accompanying text.

${ }_{23}$ See Judiciary Act of 1875 , ch. 137, 18 Stat. 470; infra notes 153-62 and accompanying text.

${ }^{24}$ See Judiciary Act of 1887, ch. 373, 24 Stat. 552, corrected by Judiciary Act of 1888 , ch. 866, 25 Stat. 433 ; infra notes $163-82$ and accompanying text.

${ }_{25}$ See 28 U.S.C. $\$ \S 1441-1447$ (1982).

${ }^{26}$ See C. WRIGHT, supra note 15, at 209. The 1948 Revision to the Judicial Code made important changes to the removal statute. Although the basic structure of removal jurisdiction remains unchanged since the 1887 statute, the reenactment recast aspects of Congress's purpose for enacting removal statutes. See H.R. REP. No. 308, 
The scope of removal jurisdiction over federal questions is related to the scope of original jurisdiction. Both sections $1331^{27}$ and $1441(b)^{28}$ empower the court to hear cases "arising under the Constitution, laws, or treaties of the United States."29 This relationship between original and removal jurisdiction is rooted in history. It was not until 1875, the same year that Congress expanded removal jurisdiction, that Congress exercised its article III authority to give federal courts general federal question jurisdiction. ${ }^{30}$

\section{B. Exercising Incidental Jurisdiction}

In a small number of cases from the nineteenth and early twentieth centuries, federal courts exercised jurisdiction over incidental state law claims joined with federal law claims. ${ }^{31}$ With the promulgation of

80th Cong., 1st Sess., Reviser's Notes (1947), reprinted at 28 U.S.C.A. $\$ 1441$ (West 1973) [hereinafter Reviser's Notes] (accompanying the revision bill, H.R. 3214, 80th Cong., 1st Sess., 93 Cong. Rec. 4115 (1947)). For a discussion of the importance of these changes in legislative purpose, see infra notes 163-72 and accompanying text.

2728 U.S.C. § 1331 (1982).

2828 U.S.C. § 1441 (b) (1982).

2928 U.S.C. $\$ 1331$ (1982); cf. 28 U.S.C. \& 1441(b) (1982) ("arising under the Constitution, treaties or laws of the United States").

${ }^{30}$ See Judiciary Act of 1875 , ch. 137, \& 1, 18 Stat. 470, 470. Judicial interpretations of $\$ \$ 1331$ and $1441(\mathrm{~b})$ acknowledge this textual and historical relationship:

Since the first version of $\S 1331$ was enacted the statutory phrase 'arising under ...' has resisted all attempts to frame a single, precise definition for determining which cases fall within, and which cases fall outside, the original jurisdiction of the district courts. Especially when considered in light of $\S 1441$ 's removal jurisdiction, the phrase "arising under" masks a welter of issues regarding the interrelation of federal and state authority and the proper management of the federal judicial system.

Franchise Tax Bd. v. Construction Laborers Vacation Trust, 463 U.S. 1, 8 (1983) (citations omitted).

${ }^{31}$ Chief Justice Marshall, in Osborn v. Bank of United States, 22 U.S. (9 Wheat.) 738 (1824), stated what is thought to be the earliest exposition of the power to hear incidental claims:

We think . . . when a question to which the judicial power of the Union is extended by the constitution[] forms an ingredient of the original cause, it is the power of Congress to give the Circuit Courts jurisdiction of that cause, although other questions of fact or of law may be involved in it.

Id. at 823 .

The first noteworthy application of this judicial power occurred in Siler v. Louisville \& N.R.R., 213 U.S. 175, 193 (1909). In that case, a state law claim was incidental to a challenge to the constitutionality of a state statute. The Supreme Court, avoiding the constitutional question, held that the circuit court could properly adjudicate the state law claim. Although the use of incidental jurisdiction to avoid constitutional adjudication limited the holding, the Court in Hurn v. Oursler, 289 U.S. 238, 243 (1933), relied on Siler to articulate broader bases for incidental jurisdiction. In Hurn, the Court exercised incidental jurisdiction to hear a patent infringement claim brought with a state claim based on unfair competition. For more discussion of Hurn, see infra note 
the Federal Rules of Civil Procedure in $1938,{ }^{32}$ however, the number of such cases increased dramatically. ${ }^{33}$ Before promulgation of the Federal Rules, federal litigants were required to follow state procedures in actions at law $^{34}$ and the Federal Equity Rules in actions in equity. ${ }^{35}$ After the Federal Rules of Civil Procedure merged law and equity, ${ }^{36}$ state procedures derived from equity that permitted more liberal joinder ${ }^{37}$ became the norm for all federal actions. ${ }^{38}$ As federal courts exercised incidental jurisdiction in a greater number of cases, the scope of original, and hence of removal, jurisdiction expanded. ${ }^{38}$

In United Mine Workers v. Gibbs, ${ }^{40}$ the Supreme Court redefined the test for incidental jurisdiction to reflect changes effected by the Rules. ${ }^{41}$ It construed article III to define the outer limits ${ }^{42}$ of a district court's authority to hear state law claims closely related to a substantial $^{43}$ federal law claim within the court's original jurisdic-

46. See generally Jurisdiction Primer, supra note 9, at 114-22 (discussing the history of incidental jurisdiction from Osborn to Hurn).

${ }^{32}$ See 308 U.S. 645 (1939).

3s See Goldberg, The Influence of Procedural Rules on Federal Jurisdiction, 28 STAN. L. Rev. 395, 416-21 (1976).

34 See Practice Conformity Act of 1872, ch. 255, § 5, 17 Stat. 196, 197.

35 See Equity Rules of 1912, 226 U.S. 627, 627-73 (1912).

ss See FED. R. Crv. P. 1; Subrin, How Equity Conquered Common Law: The Federal Rules of Civil Procedure in Historical Perspective, 135 U. PA. L. REV. 909, 961-75 (1987).

${ }^{37}$ The Equity Rules permitted the joinder of claims and parties more liberally than did most state rules for practice in actions at law. See Goldberg, supra note 33, at 416 n.112.

38 The Rules permit joinder of all claims one party has against an opposing party. See FED. R. Crv. P. 18(a). Plaintiffs may also join several defendants or join with others as multiple plaintiffs. See FeD. R. CIV. P. 20(a). Other rules permit counterclaims of all kinds against opposing parties. See FED. R. Grv. P. 13(a)-(b), and other expansive joinders; see, e.g., FED. R. CIV. P. 13(g) (cross-claims), 13(h) (addition of new parties to cross-claims), 14 (impleader), 22 (interpleader), 24 (intervention).

s9 FED. R. Crv. P. 82 states in part: "These rules shall not be construed to extend or limit the jurisdiction of the United States district courts or the venue of actions therein." The widely accepted explanation for the expansion of the incidental jurisdiction of federal courts with the liberal joinder rules of the Federal Rules has been the notion of "dormant jurisdiction." According to this view, the new Rules merely enabled courts to apply preexisting jurisdictional concepts to more broadly-defined actions. See Goldberg, supra note 33, at 417. For an argument that these procedural reforms created the need for more expansive jurisdiction to match the greater reach of the new joinder provisions, see $i d$. at $416-21$.

10383 U.S. 715 (1966).

4 See id. at 724-27.

42 In Owen Equip. \& Erection Co. v. Kroger, 437 U.S. 365, 371 (1978), the Court interpreted Gibbs to have "delineated the constitutional limits of federal judicial power."

43 Before a court can exercise incidental jurisdiction, it must find that a federal law claim in the case has "substance sufficient to confer subject matter jurisdiction on the court." Gibbs, 383 U.S. at 725; see Hurn v. Oursler, 289 U.S. 238, 246 (1933) (when "the federal question averred is not plainly wanting in substance" the court can 
tion. ${ }^{44}$ In marking the limits of that power under article III, the Court held that " $[t]$ he state and federal claims must derive from a common nucleus of operative fact." 45 This formulation replaced the test developed before the unification of law and equity, which permitted the exercise of federal jurisdiction over both state law and federal law claims when they were found to be "two distinct grounds in support of a single cause of action." ${ }^{36}$ By focusing on the facts giving rise to plaintiff's

exercise incidental jurisdiction). Because Gibbs and its progeny, see infra notes 48-58, indicate that the judicial power to hear incidental claims is constitutional, the substantiality component of incidental jurisdiction is assumed to have its source in the Constitution. See "One Constitutional Case," supra note 9, at 1417; see also infra notes 48-58 and accompanying text (discussing the statutory component of incidental jurisdiction articulated after Gibbs). For an argument that the source of the substantiality requirement of incidental jurisdiction is statutory, see "One Constitutional Case," supra note 9, at 1432-38. Whether constitutional or statutory, the general "substantial federal question" doctrine, to which the substantiality component of incidental jurisdiction is related, emerged as courts interpreted the grant of federal question jurisdiction in the Judiciary Act of 1875, ch. 137, § 5, 18 Stat. 470, 472. See infra notes 156-59 and accompanying text (discussing the 1875 Act and arguing that it demonstrates Congress's intent that a federal court have power to remand a case that was not of substantial federal character).

14 See Gibbs, 383 U.S. at 725.

15 Id. at 725. The Court also stated: "Pendent jurisdiction, in the sense of judicial power, exists whenever there is a claim 'arising under [the] Constitution, the Laws of the United States, and Treaties ...., and the relationship between ... [the federal] claim and the state claim permits the conclusion that the entire action before the court comprises but one constitutional "case." "Id.

The jurisprudence of incidental jurisdiction is an example of federal common law. See P. Bator, P. Mishikin, D. Shapiro \& H. Wechsler, Hart \& Wechsler's The Federal Courts and the Federal System 770 (2d ed. 1973) (defining federal common law to mean "rules of decision where the authority . . . is not explicitly or clearly found in federal statutory or constitutional command"); Merrill, The Common Law Power of the Federal Courts, 52 U. CHI. L. REv. 1, 5 (1985) (defining federal common law to mean "any federal rule of decision that is not mandated on the face of some authoritative federal text"). The Court has given this description of the jurisprudence of incidental jurisdiction:

Gibbs and its lineal ancestor Osborn [v. Bank of the United States, 22 U.S. (9 Wheat.) 738 (1824); see infra note 31] were couched in terms of Art. III's grant of judicial power in "Cases . . . arising under this Constitution, the Laws of the United States, and [its] treaties," since they . . . represented inquiries into the scope of Art. III jurisdiction in litigation where the "common nucleus of operative fact" gave rise to non-federal questions of claims between parties. None of them posed the need for a further inquiry into the underlying statutory grant of federal jurisdiction or a flexible analysis of concepts such as "question," "claim," and "cause of action," because Congress had not addressed itself by statute to this matter. In short, Congress had said nothing about the scope of "Cases" in Art. III which would offer guidance on the kind of elusive question addressed in Osborn and Gibbs: whether and to what extent jurisdiction extended to a parallel state claim against the existing federal defendant.

Aldinger v. Howard, 427 U.S. 1, 13-14 (1976).

s8 Hurn, 289 U.S. at 246. The Hurn test contrasted

a case where two distinct grounds in support of a single cause of action are 
claims, instead of on conflicting legal definitions of a "cause of action," the Gibbs test made incidental jurisdiction more readily applicable to state law claims. ${ }^{47}$

Since Gibbs, the Court has made clear that determining the federal court's "[c]onstitutional power" 48 to hear a state law claim is only the

\begin{abstract}
alleged, one only of which presents a federal question, and a case where two separate and distinct causes of action are alleged, one only of which is federal in character. In the former, where the question averred is not plainly wanting in substance, the federal court, even though the federal ground be not established may nevertheless retain and dispose of the cause upon the non-federal ground; in the latter it may not do so upon the nonfederal cause of action.
\end{abstract}

Id. In Hurn, the plaintiffs sought to enjoin performance of a play called "The Spider," alleging that it infringed upon their copyrighted play, "The Evil Hour." Plaintiffs also alleged that performance of "The Spider" constituted unfair competition under state law with respect to both the copyrighted version and a revised uncopyrighted version of "The Evil Hour." The Court held that there was judicial power to determine the unfair competition claim with respect to the copyrighted version of the plaintiffs' play but not as to the uncopyrighted version: "The bill . . . sets forth facts alleged to be in violation of two distinct rights, namely, the right to the protection of the copyrighted play, and the right to the protection of the uncopyrighted play." Id. at 248. Although the concept of a "cause of action" was reformed by the adoption of the federal rules and the unification of law and equity, see supra notes 31-39 and accompanying text, until Gibbs the test for incidental jurisdiction was tied to the old terminology. By keeping the cause of action test, the Court effectively authorized incidental jurisdiction only when a plaintiff sought to add a state law claim that was virtually identical to a federal law claim in the action. See "One Constitutional Case," supra note 9, at 1413. The Court in Gibbs found this test for jurisdiction by categories to be "unnecessarily grudging." Gibbs, 383 U.S. at 725.

47 In a footnote, the Court commented on the relationship between the adoption of the Federal Rules of Civil Procedure and its reformulation of the test for incidental jurisdiction: "While it is commonplace that the Federal Rules . . . do not expand the jurisdiction of federal courts, they do embody 'the whole tendency of our decisions. . . to require a plaintiff to try his . . . whole case at one time,'Baltimore S.S. Co. $v$. Phillips, [274 U.S. 316, 320 (1921),] and to that extent emphasize the basis of pendent jurisdiction." Gibbs, 383 U.S. at 725 n.13. Earlier in the opinion, discussing the cause of action test of Hurn, see supra note 46 and accompanying text, the Court quoted Baltimore S.S. Co. at length to illustrate "a case in which 'cause of action' had been used to identify the operative scope of the doctrine of res judicata." Gibbs, 383 U.S. at 723. The Court in Baltimore S.S. Co. had stated:

A cause of action does not consist of facts, but of the unlawful violation of a right which the facts show. The number and variety of the facts alleged do not establish more than one cause of action so long as their result, whether they be considered severally or in combination, is the violation of but one right by a single legal wrong.

Baltimore S.S. Co., 274 U.S. at 321, quoted in Gibbs, 383 U.S. at 723. Commenting on Hurns's citation of Baltimore S.S. Co., the Court stated "that the weighty policies of judicial economy and fairness to parties reflected in the res judicata doctrine were in themselves strong counsel for the adoption of a rule which would permit federal courts to dispose of the state as well as the federal claims." Gibbs, 383 U.S. at 724. For discussion of the claim preclusive implications of incidental jurisdiction, seè Jurisdiction Primer, supra note 9 , at 111-14 \& n.40.

${ }^{48}$ Owen Equip. \& Erection Co. v. Kroger, 437 U.S. 365, 372 (1978). 
beginning of the jurisdictional analysis. Jurisdiction over incidental claims is limited not only by the provisions of article III, but also by statutes. $^{49}$ In Aldinger $v$. Howard ${ }^{\text {so }}$ the Court held that the district court lacked jurisdiction over a state law claim, although it shared a "common nucleus of operative fact" with a federal law claim. ${ }^{51}$ The plaintiff's federal law claim against county officials arose under section 1983. ${ }^{.2}$ The Court reasoned that under the then-prevailing interpretation of section $1983^{53}$ jurisdiction over the state law claim against the county was barred because Congress had not intended a county to be subject to suit under the statute. ${ }^{54}$ Similarly, in Owen Equipment $\mathcal{E}^{\circ}$ Erection Co. $v$. Kroger, ${ }^{\mathrm{55}}$ the Court held that the complete diversity requirement ${ }^{56}$ of section $1332^{57}$ barred the district court from exercising incidental jurisdiction over the plaintiff's claim against a non-diverse third-party defendant, although that claim satisfied the Gibbs test. ${ }^{58}$

Both Aldinger and Kroger involved attempts to apply the Gibbs test to a nonfederal claim against a party not within original federal court jurisdiction. Gibbs, by contrast, involved jurisdiction over a nonfederal claim between parties already properly in federal court. Whether the Court's inquiry into statutory limits in Aldinger and Kroger constructs a test that extends beyond cases involving new parties is not clear. ${ }^{59}$ This Comment adopts a broad interpretation of these holdings and will assume that in any exercise of incidental jurisdiction "a court must attempt to discern the express or implied intent of

49 Id. at $372-73$ \& $\mathrm{n} .12$.

so 427 U.S. 1 (1976).

See id. at $16-17$.

B2 42 U.S.C. $\S 1983$ (1982).

5s Municipal corporations have since been held to be amenable to suit under $\S$ 1983. See Monell v. Department of Social Servs., 436 U.S. 658, 701 (1978).

s4 See Aldinger, 427 U.S. at 17.

ss 437 U.S. 365 (1978).

s8 See Strawbridge v. Curtiss, 7 U.S. (3 Cranch) 267, 267 (1806).

s7 28 U.S.C. $\$ 1332(\mathrm{a})(1)(1982)$.

s8 See Kroger, 437 U.S. at 373-75. The Court stated:

Beyond this constitutional minimum, there must be an examination of the posture in which the nonfederal claim is asserted and of the specific statute that confers jurisdiction over the federal claim, in order to determine whether "Congress in [that statute] has . . expressly or by implication negated' the exercise of jurisdiction over the particular nonfederal claim.

Id. at 373 (quoting Aldinger, 427 U.S. at 18). A statutory limitation on the exercise of incidental jurisdiction is evident in Zahn v. International Paper Co., 414 U.S. 291, 301 (1973). The Court in Zahn held that in a diversity class action under Federal Rule of Givil Procedure 23(b)(3) the claim of each member must satisfy the amount in controversy requirement set by $\S 1332(\mathrm{a})$. It implicitly rejected the argument that those claims that did not satisfy the requirement were "ancillary" to those that did. See Zahn, 414 U.S. at 301.

so See Jurisdiction Primer, supra note 9, at 167. 
Congress."60

Cases defining incidental jurisdiction-Gibbs, Aldinger, and Kroger-have addressed the threshold question of incidental jurisdiction: whether a federal court in its original jurisdiction initially has power to hear a state law claim. This issue is ordinarily resolved on the pleadings. ${ }^{61}$ Federal court jurisdiction over an incidental claim, however, is not a party's right. ${ }^{62}$ After a district court determines that a claim is within its constitutional power and that jurisdiction over that claim is not limited by any statute, whether the court will hear and decide the claim is within the judge's discretion. ${ }^{63}$ The Supreme Court instructs the judge to consider "judicial economy, convenience and fairness to litigants . . ." If If the federal claim is insubstantial or is dismissed before trial, the court ordinarily should dismiss the state law claims without prejudice. ${ }^{65}$ Considerations of federalism and comity should also guide the district judge's discretion. To avoid unnecessary adjudications of state law, federal courts should defer to the state courts' competence to decide questions of state law. ${ }^{66}$

With a properly removed case that contains only incidental claims, however, the court must address its power to dispose of a state law claim already within its jurisdiction. Although the court would have judicial power to decide a remaining incidental claim, ${ }^{67}$ it would, for the reasons enunciated in $G i b b s,{ }^{88}$ most likely exercise its discretion not

${ }^{80}$ See id. The commentator continues:

All federal jurisdiction is subject both to constitutional and congressional jurisdictional grants. For a court to ignore congressional intent is inconsistent with our governmental system, which separates legislative and judicial power. Congress is the branch that controls the jurisdiction of such courts. Hence, even in Gibbs-type cases, courts must search for congressional intent.

Id. at 167-68.

${ }^{61}$ See Gibbs, 383 U.S. at 727 . In the context of removal, this issue is resolved at the time the defendant petitions the district court for removal. See 28 U.S.C. \& 1446(a) (1982) (petition shall contain " $a$ short and plain statement of the facts which entitle him . . . to removal together with a copy of all process, pleadings and orders served upon him . . . in such action").

${ }_{62}$ See Gibbs, 383 U.S. at 726.

63 See id.

${ }^{B 4}$ Id.

os See id.

Bs See id. \& n.15.

67 See supra note 10 (citing cases). A federal court, following Gibbs, would also have power to dismiss the incidental claims. See Gibbs, 383 U.S. at 726.

${ }^{88}$ In the context of original jurisdiction, the Court in Gibbs described the constancy of a court's discretion over incidental claims:

The question of power will ordinarily be resolved on the pleadings. But the issue whether pendent jurisdiction has been properly assumed is one which remains open throughout the litigation. Pretrial procedures or even 
to hear the claim. Before the court can exercise its discretion and remand the case, however, it must determine the scope of section 1447 (c).$^{69}$ Because the exercise of incidental jurisdiction is limited by both article III and statutes, the court must decide whether section 1447(c) limits its power to remand.

\section{The Conflict over the Power to Remand a Properly Removed Case}

Although the Supreme Court has not precisely defined the district courts' power to remand a properly removed case, the Gourt has had opportunity, by way of petitions for mandamus, to police the exercise of the district courts' power to remand. In Thermtron Products, Inc. $v$. Hermansdorfer, ${ }^{70}$ the Court determined that mandamus should lie to compel the district judge not to remand a case properly removed to his court. ${ }^{71}$ The judge acknowledged that his reason for remanding was not one stated in the statute but determined that he had the discretion to remand the case to state court. His stated reason was that the district court's crowded docket would deny plaintiff speedy relief; litigation in state court would be faster. ${ }^{72}$ The Supreme Court intervened: "Because the District Judge remanded a properly removed case on grounds that he had no authority to consider, he exceeded his statutorily defined power; and issuance of the writ of mandamus was not barred by $\S 1447(\mathrm{~d}) . " 73$

The courts of appeals have divided in interpreting Thermtron. ${ }^{74}$

the trial itself may reveal a substantial hegemony of state law claims, or likelihood of jury confusion, which could not have been anticipated at the pleading stage. Although it will of course be appropriate to take account in this circumstance of the already completed course of the litigation, dismissal of the state claim might even then be merited. For example, it may appear that the plaintiff was well aware of the nature of his proofs and the relative importance of his claims; recognition of a federal court's wide latitude to decide ancillary questions of state law does not imply that it must tolerate a litigant's effort to impose upon it what is in effect only a state case. Once it appears that a state claim constitutes the real body of a case, to which the federal claim is only an appendage, the state claim may fairly be dismissed.

Gibbs, 383 U.S. at 727.

68 28 U.S.C. $\$ 1447$ (c) (1982).

70 423 U.S. 336 (1976).

71 See id. at 351.

72 See id. at 340-41 \& nn.3-4.

73 Id. at 351. For discussion of why mandamus was not barred in Thermtron, see infra notes $185-90$ and accompanying text.

74 Some circuits have interpreted the holding in Thermtron broadly as barring a district court from remanding a properly removed case for reasons not stated in the statute. See, e.g., Sheet Metal Workers Int'l Ass'n v. Seay, 696 F.2d 780, 782 (10th 
Some courts have reasoned that the "ground he had no authority to consider" language ${ }^{75}$ in the first clause of its holding relates to the specific facts of Thermtron..$^{78}$ The district judge's action was egregious, and mandamus should have issued in that case. But, these courts continue, the second clause does not foreclose the existence of authority to remand on other grounds not mentioned in the statute. ${ }^{77} \mathrm{~A}$ court with power to hear state law claims may dismiss them in the exercise of its discretion. In the removal context, this view concludes, a district court likewise has authority to remand state law claims. ${ }^{78}$

Other courts have given broad scope to Thermtron, reading the grant of the writ of mandamus in that case as a prohibition against all discretionary remands. ${ }^{79}$ These courts found an inconsistency between

Cir. 1983) (under the standards of Thermtron, mandamus relief is proper because the order of remand was issued on grounds unauthorized by the statutes); Levy v. Weissman, 671 F.2d 766, 769 (3d Cir. 1982) (same); Ryan v. State Bd. of Elections, 661 F.2d 1130, 1134 (7th Cir. 1981) (same); see also Cook v. Weber, 698 F.2d 907, 909 (7th Cir. 1983) (stating, without citing Thermtron, that "remand of removed cases must be based on specific statutory authority").

The Fifth Circuit initially held against any nonstatutory remand. See, e.g., In re Greyhound Lines, Inc., 598 F.2d 883, 884-85 (5th Cir. 1979) ("[P]laintiff cannot precipitate a remand of the action by amending the complaint to eliminate the federal claim." (quoting 14A C. Wright, A. Miller \& E. Cooper, Federal Practice and Procedure $\S 3722$ (1982))); In re Merrimack Mut. Fire Ins. Co., 587 F.2d 642, 644-45 (5th Cir. 1978) (mandamus appropriate when a "district court enters a remand order that is not only erroneous but also states that it is based on nonstatutory grounds"). The Fifth Circuit, however, has reversed its course. See IMFC Professional Servs. of Fla., Inc. v. Latin Am. Home Health, Inc., 676 F.2d 152, 160 (5th Cir. Unit B 1982) (A district court has "independent authority for a discretion to remand [which is derived] from the nature of the ancillary jurisdiction created by $\S 1442(a)(1) . ")$.

Other circuits hold that incidental jurisdiction provides legitimate authority on which to ground a decision to remand. See In re Romulus Community Schools, 729 F.2d 431, 440 (6th Cir. 1984) (upholding decision to remand where "judicial economy and the presence of unresolved issues of state law strongly support[ed] the district court's decision to remand"); see also Fox v. Custis, 712 F.2d 84, 89-90 \& n.4 (4th Cir. 1983) (determining, without discussing or citing Thermtron, that the court, in its discretion, could remand a properly removed incidental claim); Hofbauer v. Northwestern Nat'l Bank, 700 F.2d 1197, 1207 (8th Cir. 1983) (same); Naylor v. Case \& McGrath, Inc., 585 F.2d 557, 561-63 (2d Cir. 1978) (when state law is unsettled, district court should abstain through remand to state court).

75 Thermtron, 423 U.S. at 351.

${ }^{76}$ See Romulus, 729 F.2d at 436 ("The Supreme Court's forceful pronouncements in Thermtron against remands unauthorized by statute were prompted by the extreme circumstances of that case.").

77 See IMFC, 676 F.2d at 159-60. Judge Godbold wrote, "Thermtron does not hold . . . that there can never be an element of discretion in the remand process. Rather, discretion to remand is not prohibited by $\S 1447$ (c) or Thermtron if that discretion is based on clearly articulated authority." Id. (footnote omitted).

${ }^{78}$ See Romulus, 729 F.2d at 436-40.

78 See Carnegie-Mellon Univ. v. Cohill, No. 85-3619, slip op. at 13, 41 Fair Empl. Prac. Cas. (BNA) 1046, 1051 (3d Cir. Aug. 29, 1986), granting mandamus in Boyle v. Carnegie-Mellon Univ., 648 F. Supp. 1318 (W.D. Pa. 1985), vacated and reh'g granted, No. 85-3619, slip op., 41 Fair Empl. Prac. Cas. (BNA) 1888 (3d Cir. 
the power to remand for reasons not specified in the statute and the "fundamental constitutional principle that the jurisdiction of the inferior federal courts is dependent on specific statutory authorization."180 According to this view, the established rule that removal statutes should be strictly construed ${ }^{81}$ does not permit remand on nonstatutory grounds. The removal statutes direct when a district judge "shall" remand a case $^{82}$ and when in her discretion she "may" remand a case. ${ }^{83}$ Those who invoke the "fundamental constitutional principle" argue that this statutory scheme forecloses exercising discretion not authorized by statute. $^{\mathbf{8 4}}$

\section{The Power to Decline Vested Jurisdiction and the SEParation OF Powers}

To those who read the holding in Thermtron Products $v$. Hermansdorfer ${ }^{85}$ broadly, discretionary remand of a properly removed case violates the separation of powers. ${ }^{86}$ Proponents of this view argue that, after a case has been removed to federal court, the power to remand is dependent on the specific terms of section $1447(\mathrm{c}){ }^{87}$ A judge who remands a case for reasons not mentioned in that provision-even a case that in its present posture contains only state law

Sept. 24, 1986), affd by an equally divided court, No. 85-3619, slip op. (3d Cir. Nov. 13, 1986) (en banc), cert. granted, 107 S. Ct. 1283 (1987); Levy v. Weissman, 671 F.2d 766, 769 (3d Cir. 1982); Ryan v. State Bd. of Elections, 661 F.2d 1130, 1134 (7th Cir. 1981). The provision governing remand states that if "it appears that the case was removed improvidently and without jurisdiction, the district court shall remand the case," 28 U.S.C. \& 1447(c) (1982). These courts evidently read this language affirmatively to prohibit the remand of any properly removed case.

Bo Cohill, slip op. at 13, 41 Fair Empl. Prac. Cas. (BNA) at 1051.

81 See Shamrock Oil \& Gas Corp. v. Sheets, 313 U.S. 100, 108-09 (1941).

${ }^{82}$ See 28 U.S.C. § 1447(c) (1982).

${ }^{83}$ See 28 U.S.C. § 1441 (c) (1982).

8t See Cohill, slip op. at 13, 41 Fair Empl. Prac. Cas. (BNA) at 1051.

85423 U.S. 336 (1976).

${ }^{86}$ See Cohill, slip op. at 13, 41 Fair Empl. Prac. Cas. (BNA) at 1051.

8728 U.S.C. § 1447(c) (1982). As with incidental claims outside of the removal context, the district judge could in her discretion dismiss without prejudice a case containing only state law claims. See United Mine Workers v. Gibbs, 383 U.S. 715, 72627 (1966); cf. Cook v. Weber, 698 F.2d 907, 909 (7th Cir. 1983) ("In exercise of its sound discretion the court may retain pendent jurisdiction of the state claim, even if the federal claim which served as the basis for removal was dismissed."). The difference between dismissal and remand of state law claims becomes crucial in those states without a savings clause in their statute of limitations. See In re Romulus Community Schools, 729 F.2d 431, 439 (6th Cir. 1984). For further discussion, see infra notes 20407 and accompanying text. At this stage of the analysis, however, the issue is whether a district court has the power to remand properly removed cases at all, not whether the availability of remand would be more fair to plaintiffs whose state law claims would otherwise be barred by the running of the statute of limitations. 
claims-confronts the assertion that lower federal courts are dutybound to hear cases within their statutorily-conferred power. ${ }^{88}$

\section{A. Analogy to Abstention}

Federal courts often decline to exercise jurisdiction over cases within their power, despite statements of countervailing duty, by invoking the doctrine of abstention. Abstention is a collection of judiciallydeveloped doctrines, ${ }^{89}$ some of which require ${ }^{80}$ and others of which counsel $^{91}$ that federal courts defer to pending or potential state court proceedings. Abstention results either in a stay ${ }^{92}$ or dismissal ${ }^{83}$ of the federal actions. To counter objections based on the duty to exercise vested jurisdiction, judges have developed rationales to justify the doctrine similar to those developed for declining incidental jurisdiction: considerations of federalism, comity, and judicial efficiency. ${ }^{94}$ The prac-

${ }^{88}$ Chief Justice Marshall's dictum in Cohens v. Virginia, 19 U.S. (6 Wheat.) 264 (1821), is often cited: "We have no more right to decline the exercise of jurisdiction which is given, than to usurp that which is not given. The one or the other would be treason to the constitution." Id. at 404. More recently, Justice Brennan stated that federal courts have a "virtually unflagging obligation . . . to exercise the jurisdiction given them." Colorado River Water Conservation Dist. v. United States, 424 U.S. 800, 817 (1976).

- 89 According to one authority, these are: 1) Pullman abstention, used to avoid decision of a federal constitutional question if the case may be disposed of on state law grounds (from Railroad Comm'n v. Pullman Co., 312 U.S. 496, 501 (1941)); 2) Burford abstention, used to avoid needless conflict with a state's administration of its own affairs (from Burford v. Sun Oil Co., 319 U.S. 315, 317-18 (1943)); 3) abstention used to leave to a state the resolution of an unsettled question of state law; and 4) abstention used to avoid duplicative litigation. See 17 C. WrIGHT, A. Miller \& E. Cooper, supra note $74, \S 4241$.

so See, e.g., Younger v. Harris, 401 U.S. 37, 53-54 (1971) (holding that principles of equity, comity, and federalism require a federal court to abstain from enjoining state court proceedings, absent a showing of bad faith prosecution, where a plaintiff in federal court challenges the constitutionality of a criminal statute under which the state is prosecuting the federal plaintiff).

91 See Pullman, 312 U.S. at 501; see also County of Allegheny v. Frank Mashuda Co., 360 U.S. 185, 189 (1959) (abstention is appropriate "in cases presenting a federal constitutional issue which might be mooted or presented in a different posture by a state court determination of pertinent state law").

${ }_{92}$ See, e.g., Louisiana Power \& Light Co. v. Thibodaux, 360 U.S. 25, 30-31 (1959); Pullman, 312 U.S. at 501.

${ }^{83}$ See, e.g., Harris County Comm'rs Court v. Moore, 420 U.S. 77, 88-89 (1975); Burford, 319 U.S. at 334.

94 See Mullenix, A Branch Too Far: Pruning the Abstention Doctrine, 75 Geo. L.J. 99, 103-04 \& n.18 (1986). The rationales usually given for Pullman and Burford abstention are federalism and comity-the need for federal courts to abstain where state remedies are available and federal intervention could create friction between the federal and state systems. See Wells, The Role of Comity in the Law of Federal Courts, 60 N.C.L. Rev. 59, 61-67, 75-78 (1981); $c f .17$ C. Wright, A. Milleer \& E. Cooper, supra note 74, §§ 4242-45 (describing Pullman and Burford abstention). Courts seemingly invoke an efficiency rationale in cases where federal courts refuse to exercise 
tice of abstention lends legitimacy to judges who claim common law power to remand a properly removed case containing only incidental claims. ${ }^{95}$ Moreover, both abstention and the common law power to remand raise issues of jurisdiction, the discretion to decline its exercise, and the legitimate use of judicial power.

\section{The Strict Separation of Powers Critique}

In a recent sweeping attack upon the legitimacy of abstention, Professor Martin Redish argues that the doctrine violates the separation of powers. ${ }^{96}$ Both critics of the doctrine and those who favor it, he contends, are focusing on the wrong branch of government: the judiciary. Supporters of abstention argue that the doctrine promotes a wiser balance of judicial federalism; $; 8$ opponents seek to show the superiority of federal courts over state courts as enforcers of federal rights. ${ }^{98}$ To Redish, the arguments should be directed not to the judicial forum but to the legislative arena: "Judge-made abstention constitutes judicial

jurisdiction in deference to the expertise of a special administrative body whose remedies are still available. See, e.g., United States v. Western Pac. R.R. Co., 352 U.S. 59, 69 (1956) (deferring to the Interstate Commerce Commission's determination of the rights of the parties).

${ }^{95}$ One federal appellate court, in remanding a properly removed incidental claim after federal law claims had been dismissed, invoked the legitimacy of abstention as a possible source of the court's authority to remand. This court did not develop this analysis because it found that the doctrine of pendent jurisdiction afforded ample authority. See In re Romulus Community Schools, 729 F.2d 431, 438-39 (6th Cir. 1984).

${ }^{\circ 6}$ Redish, Abstention, Separation of Powers, and the Limits of the Judicial Function, 94 YaLE L.J. 71, 76 (1984). Redish reasons:

The principle of separation of powers between the judicial and legislative branches derives from the fundamental democratic principle of electoral accountability. The separation-of-powers critique of . . . abstention . . . begins with the analysis of the judiciary's proper role in a democratic society. The essential element of any democratic society is at least some level of majoritarian self-determination. In our form of constitutional democracy, we have chosen to vest in a largely unrepresentative judiciary the power to invalidate laws adopted by a majoritarian legislature when those laws are deemed to violate constitutional protections. It has never been suggested, however, that the judiciary may openly ignore a legislative judgment on any grounds other than unconstitutionality.

Id. (footnotes omitted).

${ }_{97}$ See, e.g., Bezanson, Abstention: The Supreme Court and Allocation of Judicial Power, 27 VAND. L. REv. 1107, 1151 (1974) (An application of the abstention doctrine, "which seeks the most efficient and reliable forum for adjudication of federal interests, is the highest form of 'cooperative judicial federalism." "); Shapiro, Jurisdiction and Discretion, 60 N.Y.U. L. REv. 543, 581 (1985) ("[E]ven in a system that is essentially 'unitary' in character, experience counsels mutual respect among the arms of government.").

${ }^{98}$ See, e.g., Neuborne, The Myth of Parity, 90 Harv. L. Rev. 1105, 1131 (1977) ("the only judicial forums in our system capable of enforcing countermajoritarian checks in a sustained, effective manner are the federal courts"). 
lawmaking of the most sweeping nature."

Under a separation of powers analysis, the issue is not the desirability of a certain judicial decision to abstain, but whether the judiciary has the power to decline jurisdiction in the first place. ${ }^{100}$ Congress has the authority both to make the basic policy decisions concerning how the nation is to be governed and to employ the federal judiciary to enforce the statutory programs it adopts. ${ }^{101}$ Absent a finding of unconstitutionality, the judiciary cannot modify or repeal jurisdictional enforcement mechanisms unless Congress has clearly delegated such authority to it. ${ }^{102}$ "Congress has retained for itself," Redish concludes, "the authority to decide when federal courts should decline to exercise their jurisdiction."

\section{The Jurisdiction and Discretion Approach}

In direct response to Professor Redish's rigorous separation of powers approach, Professor David Shapiro argues that judicial abstention in matters of jurisdiction has "ancient and honorable roots at common law as well as in equity." 104 To Shapiro, "reasoned discretion" is not only "consistent with the Anglo-American legal tradition" but also "has much to contribute to the easing of interbranch and intergovernmental tensions in our complex system of government."105 The discretion not to proceed with a case is part of the dynamic operating between legislative and judicial branches.

Shapiro interprets jurisdictional directives as empowering a federal court with a "principle of preference," a presumption that it should decide an action within the scope of the jurisdictional grant. ${ }^{108}$ This

99 Redish, supra note 96, at 114. Redish contrasts judge-made abstention with "statutorily dictated federal court abstention," id. at 81 , the network of statutes that limit the exercise of federal court power to disrupt state proceedings or interfere unduly with state policies: the Tax Injunction Act, 28 U.S.C. § 1341 (1982); the Johnson Act, 28 U.S.C. $\S 1342$ (1982); the statutory branch of the habeas corpus exhaustion requirement, 28 U.S.C. $\S 2254$ (b) (1982); the Anti-Injunction Act, 28 U.S.C. $\S 2283$ (1982); the Three-Judge Court Act, 28 U.S.C. § 2284 (1982 \& Supp. III 1985).

100 "If Congress intended that the federal courts exercise a particular jurisdiction, either to achieve substantive legislative ends or to provide a constitutionally-contemplated jurisdictional advantage, a court may not, absent constitutional objections, repeal those jurisdictional grants." Redish, supra note 96, at 77 .

${ }_{101}$ See id. at 115. "In either repealing or modifying the legislation, the court would be altering a legislative scheme because of disagreement with the social policy choices that the scheme manifests." Id. at 77.

102 See id. at 115.

${ }^{109}$ Id.

104 Shapiro, supra note 97, at 545.

105 Id.

${ }^{108}$ Id. at 575. 
principle of preference, however, will yield when the court determines that it should not proceed because of factors legitimately within the judiciary's power to consider. ${ }^{107}$ The traditional grounds for denying equitable relief provide a prime example of a federal court's inherent discretion not to proceed with certain cases within its jurisdiction. ${ }^{108}$ The principle of preference can yield to nonlegislative determinations of justiciability ${ }^{108}$ - standing, ripeness, and mootness. It can likewise yield to the judicial determination to dismiss a case for forum non conveniens. ${ }^{110}$ Judicial discretion is also involved in determining the scope of incidental jurisdiction. ${ }^{111}$

Discretion in matters of jurisdiction, for Shapiro, is not an element of any congressional grant of jurisdiction, but a function of the need for case-by-case refinement of broad statutory provisions. ${ }^{\mathbf{1 1 2}}$ Moreover, courts are especially concerned with questions of jurisdiction "because they intimately affect the courts' relations with each other as well as with the other branches of government."113 Thus, Shapiro concludes, the exercise of discretion to decline jurisdiction actually protects the

107 Id. at 547, 575 (examples of factors noted by Shapiro include "traditional equitable principles," "principles of federalism," and "principles of separation of powers").

${ }^{108} I d$. at 548. Shapiro describes Younger v. Harris, 401 U.S. 37 (1971), and its progeny as heirs to the traditional equitable considerations lead courts to refuse to enjoin proceedings in another tribunal of the same sovereign. See Shapiro, supra note 97, at $549-50$.

${ }^{109}$ Shapiro, supra note 97 , at 552-55. The requirements of justiciability flow from article III's "case or controversy" limitation. See id. (discussing U.S. CoNST. art. III, $\S 1$ ). Determination of the suitability of a "case or controversy" is the court's alone to make. See id. "[T] U.S. (1 Cranch) 137 (1803)] must be accompanied by, and indeed is founded upon, a correlative duty to decide a properly presented case in accordance with the law." Shapiro, supra note 97, at 579 (footnote omitted). Some determinations of justiciability are nonconstitutionally compelled. For example, some standing doctrine is prudential. See, e.g., Warth v. Seldin, 422 U.S. 490, 498 (1975) (plaintiff cannot sue upon a generalized grievance).

${ }_{110}$ See Gulf Oil Corp. v. Gilbert, 330 U.S. 501, 507 (1947) ("The principle of forum non conveniens is simply that a court may resist imposition upon its jurisdiction even when jurisdiction is authorized by the letter of a general venue statute."). Judicial authority to dismiss an action on grounds of forum non conveniens is similar to the authority some courts claim in order to remand a properly removed case. In both situations, although the case meet is the provisions of the statute, the court may decide that it is not the appropriate forum in which to hear the case. Of course, in forum non conveniens cases, the statutory provision not exercised concerns venue, not jurisdiction.

111 See Shapiro, supra note 97, at 555-57.

112 See id. at 574 ("[T]he question whether a court must exercise jurisdiction and resolve a controversy on its merits is difficult, if not impossible, to answer in gross. And the courts are functionally better adapted to engage in the necessary fine tuning than is the legislature.").

113 Id. 
separation of powers. ${ }^{114}$

Under this analysis of discretion, certain judicially-developed reasons to decline jurisdiction are legitimate and do not violate the separation of powers. Yet this discretion has limits. In order for the principle of preference to yield in a particular case, the court must provide an explanation for declining legislatively-granted jurisdiction that is based on the historical context in which the grant was made or the common law tradition behind it. ${ }^{115}$

\section{B. Declining Incidental Jurisdiction and the Limits of Section 1447(c)}

\section{The Strict Separation of Powers Approach}

Promoters of the broad interpretation of Thermtron can find support in Professor Redish's rigorous separation of powers approach. Congress passed the removal statutes as part of the enforcement scheme for its statutory programs. Providing for removal jurisdiction indicates Congress's policy determination that defendants can choose to litigate certain cases in a federal forum, as opposed to a state forum. If under section $1441(\mathrm{~b})^{118}$ a defendant can properly remove a case containing both state law and federal law claims, then the district court to which such a case is removed cannot remand it. Unless dismissed, the court is dutybound to hear and decide the entire case.

Furthermore, under this broad interpretation, remand statutes specifically indicate when judges can deny a federal forum to state court litigants. The specificity of Congress's provisions for remand belies any notion that Congress has delegated to the judiciary the authority to decide when to remand properly removed cases. ${ }^{117}$ Discretionary remand of any properly removed case would counter congressional intent as expressed in section 1447 (c). ${ }^{118}$ Although it is contrary to judicial con-

114 See id.

${ }^{116}$ Id. at 575. Shapiro cites Congress's grant of the Supreme Court's certiorari jurisdiction as an example of the historical context of the grant rendering the Court's discretion virtually absolute. See id. at 575-76. Shapiro contrasts the post-Civil War civil rights jurisdictional grant and remedial provision as an example of a "special jurisdictional statute . . . [that] might well tip the scales in favor of little or no discretion. Id. at $576-77$.

${ }_{116} 28$ U.S.C. $\& 1441$ (b) (1982).

117 This position finds support in dictum from Thermtron. "[W]e are not convinced that Congress ever intended to extend carte blanche authority to the district courts to revise the federal statutes governing removal by remanding cases on grounds that seem justifiable to them but which are not recognized by the controlling statute." Thermtron, 423 U.S. at 351.

${ }^{118}$ But of. infra notes 140-56 and accompanying text (discussing $\S 1441$ (c) and 
cerns for federalism and comity for a federal court, absent diversity, to hear a case containing only state law claims, the judiciary cannot substitute its concerns for Congress's policy determinations. ${ }^{119}$ It is for Congress to determine whether remanding such a properly removed case is proper. If Congress decides that federal jurisdiction is not appropriate in this situation, then Congress should amend the statute. ${ }^{120}$

\section{The Jurisdiction and Discretion Approach}

Professor Shapiro's approach results in a different analysis. Using his terms, sections 1441(b) and 1447(c) represent a principle of preference that district courts should hear and decide a properly removed case. ${ }^{121}$ If, however, a reason for remand not stated in the statute can be supported in the historical context in which Congress granted removal and remand jurisdiction, a properly removed case can be remanded without exceeding statutory limits. The reason given by the district judge for remanding Thermtron-his crowded docket-provides an example of jurisdictional discretion that cannot be supported by leg-

its predecessor statutes, which grant district courts the power to remand incidental claims after removal).

119 Under Redish's approach, only if a removal provision were unconstitutional could the judiciary deny the will of Congress. See supra note 96 and accompanying text. The constitutionality of removal jurisdiction is settled. See supra note 17 and accompanying text.

${ }_{120}$ The American Law Institute has proposed an amendment to the remand statute that would grant district courts the power to remand incidental claims:

In any case removed to a district court of the United States . . . in which claims arising under State law remain pending after disposition of the federal claim, defense, or counterclaim that is the basis for jurisdiction, the district court shall have discretion either to adjudicate the remaining State claims, or, if it finds that determination of such claims in a State court is in the interest of justice and not prejudicial to the parties, to remand the case to the State court.

American Law Institute, Study of Division of Jurisdiction Between State AND Federal Courts $\S 1313$ (d) (1968). The ALI proposal is part of its comprehensive restatement of removal jurisdiction that also includes permitting removal on the defendant's pleading of a federal defense. See id. $\$ 1312$ commentary. Under the current well-pleaded complaint rule, a federal defense is not sufficient to vest original jurisdiction in a federal court and, thus, cannot support removal. See Louisville \& N.R.R. v. Mottley, 211 U.S. 149, 253 (1908) (" 'a suggestion of one party, that the other will or may set up a claim under the Constitution or laws of the United States, does not make the suit one arising under that Constitution or those laws" (quoting Tennessee v. Union \& Planters Bank, 152 U.S. 454, 464 (1894))); see also Comment, Federal Preemption, Removal Jurisdiction, and the Well-Pleaded Complaint Rule, 51 U. CHI. L. REv. 634, 636-46 (1984) (discussing the application of the well-pleaded complaint rule in removal jurisdiction). See infra note 159 and accompanying text.

121 This principle is inferred from the statute's command that cases removed "improvidently and without jurisdiction" shall be remanded. 28 U.S.C. $\S 1447$ (c) (1982). 
islative history. ${ }^{122}$ Under Shapiro's case-by-case approach to interpreting jurisdictional grants, however, the determination that the district judge in Thermtron had violated the statute is limited to the facts of that case. Whether remanding a different case-one under section 1441(b) that in its present posture contains only state law claims-would violate section 1447 (c) requires further inquiry into the history of the removal and remand statutes.

\section{Recognizing the Judiciary's Common Law Authority over Incidental Jurisdiction}

The separation of powers principle in this context concerns judicial intrusion into the lawmaking function of Congress. Confronted with a properly removed case containing only state law claims, the question is whether a court encroaches upon Congress's power to control what happens to a case after removal by remanding. Under Professor Redish's approach, the inference can be made from section 1447 (c) that the statute prohibits the remand of any properly removed case. The court that remands imposes its own determination about what should happen to a case after proper removal. As with abstention, such an exercise of discretion conflicts with statutory command.

This view of jurisdictional authority based strictly on statute fails to account for a federal court's common law authority over incidental claims. A court determining whether it has jurisdiction to hear an incidental claim along with a federal law claim first decides whether the state law claim is within the court's "constitutional power." If the federal law claim is substantial and the claims derive from a "common nucleus of operative fact," then the incidental claim has crossed the "first hurdle." 123 A court must then determine whether any statute limits its discretionary exercise of incidental jurisdiction. ${ }^{124}$ This inquiry, however, does not assume that a jurisdictional statute restrictively $d e-$ fines all permissible exercises of judicial power.

With its emphasis on judicial discretion, Professor Shapiro's approach better accommodates questions involving incidental jurisdiction than does the strict statutory approach. Shapiro would examine the historical context in which Congress enacted section 1447(c) to determine whether an exercise of jurisdictional discretion is compatible with the

${ }^{122}$ The Supreme Gourt commented: "That justice may move more slowly in some federal courts than in their state counterparts is not one of the considerations that Congress has permitted the district courts to recognize in passing on remand issues." Thermtron, 423 U.S. at 351.

${ }_{123}$ Owen Equip. \& Erection Co. v. Kroger, 437 U.S. 365, 372 (1978).

${ }^{124}$ See supra note 58 and accompanying text. 
statute. This Comment argues that the Supreme Court will likewise analyze the history of section 1447 (c) to determine whether its purpose limits a federal court's common law power over incidental state law claims.

\section{Congress's Purpose in Enacting Removal Jurisdiction}

This Part examines whether Congress, in granting removal jurisdiction, conferred on defendants a right to have the incidental claims of a case removed from state court decided in federal court. Specifically, it examines the removal statutes enacted between 1866 and 1887 to determine whether Congress intended the predecessor to section $1447(\mathrm{c}),{ }^{125}$ originally enacted in $1887,,^{128}$ to prevent the remand of incidental claims. More generally, it asks whether Congress intended a federal court to treat incidental claims differently in its removal jurisdiction than in its original jurisdiction.

By enacting section $1331,{ }^{127}$ Congress did not çonfer on litigants a right to have incidental claims heard in federal court. ${ }^{128}$ Because Congress employed similar language in sections 1331 and $1441(a)^{129}$ to confer on federal courts the power to hear cases "arising under" federal law, courts explicitly tie the scope of removal jurisdiction to the scope of original jurisdiction. ${ }^{130}$ This relationship leads some courts to dispose of a case under section 1441(a) that contains only state law claims in the same fashion that it would dispose of a similar case under section $1331 .{ }^{131}$ In neither context, the argument runs, would a federal court decide the case. It would either be dismissed or remanded.

Removal jurisdiction, however, serves a different purpose than does original jurisdiction. Congress granted removal jurisdiction in order to provide a defendant in state court the right to litigate in a federal

12828 U.S.C. $\S 1447$ (c) (1982).

${ }^{128}$ See Judiciary Act of 1887 , ch. 373,24 Stat. 552, corrected by Judiciary Act of 1888 , ch. 866, 25 Stat. 433; infra notes $152-53$ and accompanying text.

${ }_{127} 28$ U.S.C. $\S 1331$ (1982).

${ }^{128}$ The Supreme Court has said that congressional silence on the question of incidental jurisdiction has left the situation "open for the Court to fashion its own rules under the general language of Art. III." Aldinger v. Howard, 427 U.S. 1, 15 (1976). United Mine Workers v. Gibbs, 383 U.S. 715 (1966), stated that pendent jurisdiction is not a party's right, but "a doctrine of discretion." Gibbs, 383 U.S. at 726. But see 28 U.S.C. $\S 1338$ (b) (1982) (granting federal courts jurisdiction to hear "a claim of unfair competition when joined with a substantial and related claim under the copyright, patent, plant variety protection, or trademark laws" and codifying Hurn v. Oursler, 289 U.S. 238, 245-46 (1933)).

12828 U.S.C. § 1441(a) (1982).

1so See supra notes $27-30$ and accompanying text.

131 See supra notes 85-88 and accompanying text. 
forum. If Congress intended this right to extend to a defendant's entire case, including incidental claims, then the removal statutes could be interpreted as establishing a right to have incidental claims adjudicated by a federal court. The terms of the remand statute would implement legislative policy. ${ }^{132}$ Section 1447 (c) would forbid the remand of a properly removed case, including a case that contained only state law claims. ${ }^{13 s}$

Determining whether Congress ever intended federal question removal jurisdiction to confer a right to have incidental claims adjudicated is problematic. ${ }^{134}$ As noted, for the most part Congress has been silent on the issue of state law claims incidental to federal questions. Moreover, during the period when Congress set the basic structure of removal jurisdiction-from the Civil War to the Judiciary Act of $1887^{135}$ _concepts of judicial power over incidental claims had not yet been formed into doctrine. Coherent judicial approaches to incidental jurisdiction were not identifiable until the early twentieth century and were not applied with frequency until the adoption of the Federal Rules in $1938 .^{138}$ Finally, the Supreme Court's decision in Erie R.R. $v$. Tompkins $^{\mathbf{1 3 7}}$ that federal courts must apply state law to state claims has become a crucial consideration for courts deciding whether to hear a state law claim. ${ }^{138}$ Erie and its progeny sharpen the argument that, aside from diversity cases, a case containing only state law claims

132 Congress's authority to enforce its policy concerning the relationship between federal and state courts would control the force of judicially-defined common law.

193 If Congress intended removal jurisdiction to confer a right to have incidental claims adjudicated, then, under Owen Equip. \& Erection Co. v. Kroger, 437 U.S. 365 (1977), and Aldinger, the court would have to conclude that "Congress in [that statute] has ... expressly or by implication negated' the exercise of jurisdiction over the nonfederal claim." Kroger, 437 U.S. at 373 (quoting Aldinger, 427 U.S. at 18). In this context, the exercise of jurisdiction that would be negated would be the discretion to remand a nonfederal claim.

134 One commentator captures this difficulty well:

This quest for congressional intent is largely a quest for implied intent. Congress has expressed its views on the propriety of pendent and ancillary jurisdiction only infrequently. Thus, the major problem for courts applying Aldinger and Kroger is discovering when implied congressional intent creates a jurisdictional limitation. Courts must ask a most imponderable question: what would Congress think about an issue to which it has given no express thought?

Jurisdiction Primer, supra note 9, at 168 (citing 28 U.S.C. $§$ 1338(b) (1982)); see also supra note 9 and accompanying text.

195 Ch. 373, 24 Stat. 522; see supra note 26 and accompanying text.

${ }_{136}$ See supra notes 31-39 and accompanying text.

137304 U.S. 64 (1938).

198 "Needless decisions of state law should be avoided both as a matter of comity and to promote justice between the parties, by procuring for them a surer-footed reading of applicable law." United Mine Workers v. Gibbs, 383 U.S. 715, 726 (1966). 
should be decided in state court. ${ }^{\mathbf{1 3 9}}$

\section{A. Removal Jurisdiction and Incidental Claims Between the Civil War and 1887}

Although Congress has remained silent on the issues of incidental claims and general federal question jurisdiction, both original and removal, it has addressed the issue of incidental claims and diversity jurisdiction in the removal context. The series of diversity removal statutes that Congress passed between the Civil War and 1887 reveal a general policy regarding federal court adjudication of incidental claims in removed cases. These statutes, especially the predecessors of section 1441(c), demonstrate Congress's intent not to confer on state court defendants the right to have incidental claims adjudicated by a federal court after removal. Furthermore, they provide positive evidence of what Congress might have done had it addressed the issue of federal question jurisdiction and incidental claims in the removal context.

\section{Removal Jurisdiction Through 1875}

Congress passed two statutes soon after the end of the Civil War that foreshadowed the great expansion of federal power in the Judiciary Act of $1875 .{ }^{140}$ The Separable Controversy Act of $1866,{ }^{141}$ the first predecessor statute to section 1441 (c), responded to southern abuse of the statutory requirements of diversity jurisdiction. Since Strawbridge v. Curtiss, ${ }^{142}$ the Supreme Court has interpreted the statute granting federal courts diversity jurisdiction as requiring complete diversity between parties to a suit. ${ }^{143}$ Southerners thwarted defendants' efforts to

${ }^{139}$ If $\S 1441$ (b) were held to establish a right to have incidental claims adjudicated, Erie concerns would not support a federal court's decision to remand a case containing only state law claims. Federal courts regularly decide state law claims under their diversity jurisdiction. See 28 U.S.C. $\S 1332$ (1982); $c f$. Meredith v. Winter $\mathrm{Ha}$ ven, 320 U.S. 228,234 (1943) ("[T]he difficulties of ascertaining what the state courts may hereafter determine the state law to be do not in themselves afford a sufficient ground for a federal court to decline to exercise its jurisdiction to decide a case which is properly brought to it for decision.").

${ }_{110}$ Ch. 137, 18 Stat. 470.

141 Separable Controversy Act of 1866, ch. 288, 14 Stat. 306. The bar and bench gave this statute its popular title. The words "separable controversy" do not appear in the statute. See, e.g., Richard v. National City Bank, 6 F. Supp. 156, 157 (S.D.N.Y. 1934) (using the popular title). See generally Comment, The Constitutionality of Federal Removal Jurisdiction over Separable Controversies Involving Citizens of the Same State, 94 U. PA. L. REv. 239 (1946) (discussing the early history of the removal doctrine).

${ }_{142} 7$ U.S. (3 Cranch) 267, 267 (1806).

143 See, e.g., Owen Equip. \& Erection Co. v. Kroger, 437 U.S. 365, 373 (1978) (" $[\S 1332(a)(1)]$ and its predecessors have consistently been held to require complete 
remove from state court by joining nominal nondiverse defendants to the suit. ${ }^{144}$ The Separable Controversy Act permitted a defendant to split causes of action and to remove to federal court that portion of a case that satisfied the statutory diversity requirement. ${ }^{145}$ The statute explicitly mentioned a plaintiff's right to proceed in state court against the remaining nondiverse defendants. ${ }^{\mathbf{4 6} 6}$

Congress amended the Separable Controversy Act the following year ${ }^{\mathbf{1 4 7}}$ to permit a litigant to remove merely by filing an affidavit "stating that he has reason to and does believe that, from prejudice or local influence, he will not be able to obtain justice in such state court . . . "148 The Prejudice or Local Influence Act of $1867^{149}$ was the first general removal statute that permitted both plaintiffs and defendants to remove. It allowed removal when there was "controversy between a citizen of the state in which the suit is brought and a citizen of another State ...."160 Unlike the 1866 Act, the 1867 amendment made no mention of postremoval state court proceedings. Subsequently, some litigants attempted to remove their entire suits, both federal and state causes, to federal court. In 1873, the Supreme Court, in The Sewing Machine Cos. Case, ${ }^{151}$ ruled against this practice, holding that the Prejudice or Local Influence Act and the Separable Controversy Act

diversity of citizenship."). Complete diversity is not a constitutional requirement. See State Farm Fire \& Casualty Go. v. Tashire, 386 U.S. 523, 530-31 (1967) (upholding construction of the interpleader statute, 28 U.S.C. $\$ 1335$ (1982), as requiring only "minimal diversity," concluding that "Article III poses no obstacle to the legislative extension of federal jurisdiction, founded on diversity, so long as any two adverse parties are not co-citizens").

144 See infra note 160 and accompanying text.

145 See Separable Controversy Act of 1866, ch. 288, 14 Stat. 306:

[I]f the suit is one in which there can be a final determination of the controversy, so far as it concerns him, without the presence of the other defendants as parties in the cause, then and in every such case the alien defendant, or the defendant who is a citizen of a State other than that in which the suit is brought, may, at any time before the trial or final hearing of the cause, file a petition for the removal of the cause . . .

Id., 14 Stat. at 306-07.

148 The statute states:

[S]uch removal of the cause, as against the defendant petitioning therefor, into the United States court, shall not be deemed to prejudice or take away the right of the plaintiff to proceed at the same time with the suit in the state court as against the other defendants, if he shall desire to do so.

$I d ., 14$ Stat. at 307.

147 See Prejudice or Local Influence Act of 1867, ch. 196, 14 Stat. 558.

${ }_{148}$ Id., 14 Stat. at 559.

149 Ch. 196, 14 Stat. 558.

${ }^{180}$ Id. Either a plaintiff or a defendant had been able to remove under jurisdictional provisions governing land title suits involving a title under a grant from a state other than when the suit was pending. See supra notes 18-19 and accompanying text. 15185 U.S. (18 Wall.) 553 (1873). 
did not alter the complete diversity requirement. A party could not remove an entire suit to federal court without complete diversity. ${ }^{\mathbf{1 5 2}}$

Congress reversed Sewing Machine by enacting the Judiciary Act of 1875. Congress combined the "separable controversy" element of the 1866 Act with the right of either party to remove granted by the Prejudice or Local Influence Act. The 1875 Act permitted both plaintiffs and defendants to remove an entire suit from state court if the real controversy was between diverse parties. ${ }^{153}$ Like the 1867 Act, the legislation did not include the language from the 1866 Act concerning the right of a plaintiff to continue litigating in state court against nondiverse defendants. ${ }^{154}$ The 1875 Act, therefore, granted federal courts removal jurisdiction to adjudicate incidental claims-claims between nondiverse parties joined with claims that satisfied the complete diversity requirement. ${ }^{105}$ In contrast, a case containing claims between diverse parties joined with claims between nondiverse parties could not have been brought in federal court originally. No provision in the 1875 Act governing original diversity jurisdiction changed the statutory requirement of complete diversity.

${ }^{152}$ The Court recognized that the language describing the diversity of citizenship needed for removal in the Prejudice and Local Influence Act of 1867 was different from the language of the Judiciary Act of 1789, ch. 20, 1 Stat. 73. See Sewing Machine, 85 U.S. (18 Wall.) at 585. And although the 1867 Act extended removal to plaintiffs, the Court still held that the construction of the 1789 Act in Strawbridge v. Curtiss, 7 U.S. (3 Cranch) 267 (1806), controlled. "Either the non-resident plaintiff or non-resident defendant may remove the cause under the last-named act, provided that all the plaintiffs or all the defendants join in the petition, and all the party [sic] petitioning are nonresidents, as required under the Judiciary Act . . ." Sewing Machine, 85 U.S. (18 Wall.) at 587.

${ }_{18 s}$ The Act provides, in relevant part:

$[W]$ hen . . . there shall be a controversy which is wholly between citizens of different States, and which can be fully determined as between them, then either one or more of the plaintiffs or defendants actually interested in such controversy may remove said suit into the circuit court of the United States ....

Judiciary Act of 1875, ch. 137, 18 Stat. 470, 471.

184 The 1875 Act contained nothing concerning removal on the specific ground of prejudice or local influence. The Act, however, did not repeal the relevant section of the recent codification of federal law. See Revised Statutes, ch. 7, § 639, cl. 3, 18 Stat. 114 (1874). The new code took effect June 22, 1874 and, like the 1867 Act, provided for removal by a plaintiff or defendant who submitted an affidavit stating "prejudice or local influence." Id., reprinted in 28 U.S.C.A. $\S 1441$, historical and revision notes (West 1973).

${ }_{185}$ The Supreme Court upheld the 1875 removal provision in Barney v. Latham, 103 U.S. 205 (1880). That case involved a land conveyance from a local corporation to resident and nonresident heirs of the original recipient. The Court concluded that Congress intended the removal of the separable controversy between diverse parties to transfer the entire suit to federal court. The Court stated: "That such was the intention of Congress is a proposition which seems too obvious to require enforcement by argument." Id. at 212 . 
That removal jurisdiction after 1875 extended to claims that could not have been brought in federal court originally should not be interpreted to mean that Congress intended courts to treat incidental claims differently in its removal jurisdiction than in its original jurisdiction. The 1875 Act also granted the federal courts power to determine whether any suit in federal court "at any time after such suit has been brought or removed thereto . . . does not really and substantially involve a dispute or controversy properly within the jurisdiction of [the] court" and to "dismiss the suit or remand it . . . as justice may require ...."1s6 Congress clearly contemplated that a federal court's power to dispose of a case not substantially federal in character was to be the same in its original or removal jurisdictions.

Congress's effort to expand federal judicial power with the 1875 Act extended beyond diversity jurisdiction. This statute granted federal courts, for the first significant period of time, original and removal jurisdiction over all questions "arising under" federal law. ${ }^{157}$ Because Congress chose to enact general federal question jurisdiction with the same "arising under" language contained in article III, the 1875 Act might be read to grant federal courts all the jurisdiction constitutionally permissible. ${ }^{158}$ Judicial interpretations of the 1875 Act, however, read

158 Judiciary Act of 1875 , ch. $137, \S 5,18$ Stat. 470,472 (emphasis added). This provision is critical because it demonstrates that Congress, even as it granted the broadest federal jurisdiction in history, intended a federal court to have power to remand a case that was not of substantial federal character. It states in full:

That if, in any suit commenced in a circuit court or removed from a State court to a circuit of the United States, it shall appear to the satisfaction of said circuit court, at any time after such suit has been brought or removed thereto, that such suit does not really and substantially involve a dispute or controversy properly within the jurisdiction of said circuit court, or that the parties to said suit have been improperly or collusively made or joined, either as plaintiffs or defendants, for the purpose of creating a case cognizable or removable under this act, the said circuit court shall proceed no further therein, but shall dismiss the suit or remand it to the court from which it was removed as justice may require ... but the order of said circuit dismissing or remanding said cause to the State court shall be reviewable by the Supreme Court on writ of error or appeal, as the case may be.

$I d$.

157 See ch. 137, 18 Stat. 470, 470 (1875). See supra note 19 (noting the period between 1801-02 during which Congress granted and repealed general federal question jurisdiction).

158 See Mishkin, The Federal "Question" in the District Courts, 53 Colum. L. Rev. 157, 160 \& n.22 (1953) (noting legislative history of the 1875 Act and suggesting that it was meant to confer "the full range of constitutional power"); $c f$. Pacific R.R. Removal Cases, 115 U.S. 1, 11-14 (1885) (construing the "arising under" language of the 1875 Act to have the broad meaning given by Chief Justice Marshall in Osborn v. Bank of the United States, 22 U.S. (9 Wheat.) 738, 817-28 (1825)). 
its language more narrowly than that of the Constitution. ${ }^{\mathbf{1 5 9}}$ In legislating broad national judicial power, Congress displayed its distrust of the justice available in state courts. From one perspective, the 1875 Act was the culmination of Reconstruction. Southern defiance of national policy had led Congress to redefine federalism to assert national authority over the South. ${ }^{\mathbf{1 6 0}}$ From another perspective, the 1875

150 Judicial construction of the Act introduced requirements that limited the scope of federal question jurisdiction. The first appearance of the substantiality doctrine-making the presence of a substantial federal question a prerequisite to lower federal court jurisdiction-was in Gold-Washing \& Water Co. v. Keyes, 96 U.S. 199 (1877). See "One Constitutional Case," supra note 9, at 1433 (arguing that the origin of the substantial federal question test is statutory and not constitutional); supra note 43 (discussing the substantiality component of federal question incidental jurisdiction). In Gold-Washing, the Court held that, before federal question jurisdiction can attach, a court must find "that the suit is one which 'really and substantially involves a dispute or controversy' as to a right which depends upon the construction or effect of the Constitution, or some law or treaty of the United States." Gold-Washing, 96 U.S. at 20304. Although the Court did not explicitly state the source of the substantiality requirement, the 1875 Act contained the language "really and substantially involve a dispute or controversy." Judiciary Act of 1875 , ch. 137, § 5, 18 Stat. 470, 472. Modern statements of the substantiality requirement have lessened its stricture. See, e.g., Duke Power Co. v. Carolina Envtl. Study Group, 438 U.S. 59, 70 (1978) (stating the test as "whether 'the cause of action alleged is so patently without merit as to justify . . . the court's dismissal for want of jurisdiction." (citation omitted)).

Gold-Washing also held that "[b]efore . . . a circuit court can be required to retain a cause under [federal question] jurisdiction, [the federal question] must in some form appear on the record, by a statement of facts, 'in legal and logical form,' such as is required in good pleading . . . ." Gold-Washing, 96 U.S. at 203 (citation omitted). This states the "well-pleaded complaint" rule. See "One Constitutional Case," supra note 9, at 1436. Had the defendants in Gold-Washing pleaded a substantial federal question, they would have been permitted to remove. Under the 1875 Act, a defendant could remove even if the claim "arising under" federal law appeared as a defense in the answer. See Pacific R.R. Removal Cases, 115 U.S. at 11; Provident Sav. Life Assurance Soc'y v. Ford, 114 U.S. 635, 642 (1885); see also Tennessee v. Union \& Planters' Bank, 152 U.S. 454, 460 (1894) (stating that under the 1875 Act "it was held sufficient to justify a removal by the defendant that the record at the time of the removal showed that either party claimed a right under the Constitution or laws of the United States"). The appearance of a federal defense would not have been sufficient to confer original jurisdiction. See Metcalf v. Watertown, 128 U.S. 586, 589 (1888) (construing the 1875 Act: "Where . . . the original jurisdiction . . . is invoked upon the sole ground that the determination of the suit depends upon some question of a Federal nature, it must appear, at the outset, from the declaration or the bill of the party suing, that the suit is of that character. . . ."). It was not until the Court interpreted the Judiciary Act of 1887 that removal was held not to attach unless a federal claim appeared on the face of a plaintiff's well-pleaded complaint. See Union \& Planters' Bank, 152 U.S. at 462 (construing the 1887 removal statute as "limiting the jurisdiction of a Circuit Court of the United States . . . to such suits as might have been brought in that court by the plaintiff . . . ."); id. at 469 (Harlan, J., dissenting) (stating that the opinion of the Court was an "erroneous interpretation of the statute" and that it was "too narrow"); see also supra note 120 (discussing the ALI's proposed amendment to the removal statute that would permit removal upon defendant's pleading of a federal defense).

${ }^{160}$ See S. KUTLER, supra note 19, at 145-46; Wiecek, The Reconstruction of Federal Judicial Power, 1863-1875, 13 AM. J. Legal HIST. 333, 338-42 (1969). The passage of civil rights statutes to enforce the federally-guaranteed rights of the thir- 
Act demonstrated Congress's concern for the needs of the national business enterprises that emerged during this period. ${ }^{\mathbf{1 0 1}}$ Some commentators have suggested that the real purpose behind the 1875 Act was to remedy the increasing number of attacks on railroad interests in state courts. ${ }^{162}$ Whatever the mix of motives, Congress in 1875 struck a fundamentally new balance between state and federal courts. Even at this high point of federal jurisdiction, however, a litigant who removed a case to federal court could not claim a right to have incidental claims decided there.

\section{The Judiciary Act of 1887}

By 1887 , the nationalism of Reconstruction had completely receded, although railroads were still frequent defendants in state court suits. ${ }^{163}$ Congress reversed its course and restricted access to federal court with the Judiciary Act of $1887 .{ }^{164}$ The Act limited the availability of removal to state court defendants and raised the amount in controversy requirement from $\$ 500$ to $\$ 2000 .^{165}$

The 1887 Act did, however, retain elements of the federal jurisdictional expansion of the post-Civil War period. It retained the "separable controversy" provision that had first appeared in the 1866 Act, including the expanded coverage of incidental claims that the 1875 Act

teenth, fourteenth, and fifteenth amendments also greatly expanded federal judicial power. See generally Developments in the Law, "Section 1983 and Federalism," 90 HARV. L. REv. 1133, 1141-56 (1977) (outlining the development of the civil rights laws).

161 During the floor debate concerning amendments to this legislation, Senator Matt Carpenter commented on the national character of commerce and the fact that since 1789 the American people had "become totally changed in their methods of doing business . . . " 2 CONG. REC. 4986 (1874).

162 See F. Frankfurter \& J. Landis, The Business of the Supreme Court 64-65 (1928). Corporations indeed took advantage of removal provisions. See, e.g., $P a-$ cific R.R. Removal Cases, 115 U.S. at 11 (suit by federally chartered corporation removable "on the ground that such suits are suits 'arising under the laws of the United States" "); Barney v. Latham, 103 U.S. 205, 212 (1880) (corporation seeking to remove; constitutionality of 1875 separable controversy provision upheld). The outcome in the Pacific Railroad cases permitted railroads to litigate in federal court an enormous number of cases that traditionally had been decided in state courts. The decision opened federal courts to a deluge of tort and corporate cases. See S. KuTLER, supra note 19, at 157. Congress has since reversed Pacific Railroad. See 28 U.S.C. $\S 1349$ (1982) ("The district courts shall not have jurisdiction of any civil action by or against any corporation upon the ground that it was incorporated by or under an Act of Congress, unless the United States is the owner of more than one-half of its capital stock.").

${ }_{103}$ See supra note 162 and accompanying text.

164 Ch. 373, 24 Stat. 552 (1887). To correct stenographic errors in recording the statute, Congress passed the Judiciary Act of 1888, ch. 866, 25 Stat. 433.

${ }_{165}$ See Judiciary Act of 1888, ch. 866, 25 Stat. 433, 434; Judiciary Act of 1887, ch. 373,24 Stat. 552, 552-53. 
had established. Although the 1887 provision was limited to defendants, a litigant who had a separable controversy against a plaintiff of diverse citizenship could remove the entire case. ${ }^{166}$ Under both the 1875 and 1887 Acts, a federal court had power to decide incidental claims. ${ }^{167}$

Congress reemployed the "prejudice or local influence" provision of the 1867 Act that had been deleted from the broad language of the $1875 \mathrm{Act}^{168}$ but added a new and significant proviso. After establishing that local bias would prevent justice in state court, a defendant could remove the entire suit to federal court. If, however, the court determined that the bias did not pertain to other defendants, it could in its discretion remand that part of the case concerning those defendants. ${ }^{169}$ Furthermore, the statute directed the court to "examine into the truth

${ }_{186}$ The $1887 \mathrm{Act}$ did not reinstate the provision from the 1866 Act that had permitted a plaintiff to proceed against nondiverse defendants in state court after defendants of diverse citizenship had removed.

${ }_{167}$ As has been noted, the "separable controversy" provision that originated in the 1866 Act, see supra note 141 and accompanying text, was the predecessor to $\S 1441$ (c). The 1948 revision to the judicial code amended the statute to permit removal of a "separate and independent claim or cause of action." 62 Stat 937, 938. Congress's purpose in the 1948 revision was to abridge the right of removal. See American Fire \& Casualty Co. v. Finn, 341 U.S. 6, 9-11 (1951); Reviser's Notes, supra note 26, at 5.

Prior to 1948 , the separable controversy provision applied only to diversity cases. The 1948 revision extended the provision to include any separate and independent claim, thereby raising serious constitutional questions. If a federal law claim is joined with a separate and independent state law claim, and diversity is absent, a federal court that adjudicates the state law claim would seem to transgress the boundary of article III that delineates permissible exercises of judicial power. See United Mine Workers v. Gibbs, 383 U.S. 715, 725 (1966); see also Cohen, Problems in the Removal of a "Separate and Independent Claim or Cause of Action", 46 MINN. L. REv. 1, 39 (1961) (questioning the constitutionality of removing a "separate and independent" claim along with an otherwise removable federal question).

${ }_{188}$ This provision remained in the removal statute until the 1948 revision to the judicial code. The Reviser's Notes to the 1948 revision explained why Congress discarded the "prejudice or local influence" language:

These provisions, born of the bitter sectional feeling engendered by the Civil War and the Reconstruction period, have no place in the jurisprudence of a nation since united by three wars against foreign powers. Indeed, the practice of removal for prejudice or local influence has not been employed much in recent years.

Reviser's Notes, supra note 26, at 5. After the 1948 revision, therefore, any argument that Congress granted defendants the right to have state law claims of a case removed from state court adjudicated along with federal law claims by a federal court in order to avoid the bias of state court is untenable.

${ }_{169}$ The Judiciary Act of 1888 provided:

[I]f it further appear that said suit can be fully and justly determined as to the other defendants in the State court, without being affected by such prejudice or local influence, and that no party to the suit will be prejudiced by a separation of the parties, said circuit court may direct the suit to be remanded, so far as relates to such other defendants . . . .

Id., 25 Stat. at 435. 
of said affidavit .... and, unless it shall appear to the satisfaction of said court that said party will not be able to obtain justice in such State court, it shall cause the same to be remanded thereto."170 By couching broad discretion in obligatory language, Congress in effect created a scheme whereby the judiciary did not have to hear any cases removed under the prejudice or local influence provision. Finally, the 1887 Act included a provision that directed a federal court to remand any "improperly removed" case. ${ }^{171}$ Congress directed that remands be "immediately carried into execution" and forbade appellate review, either by appeal or extraordinary writ. ${ }^{172}$

\section{Congress's Purpose in Providing Removal Did Not Include Jurisdiction over Incidental Claims}

Under the 1887 Act, it was technically possible to have incidental claims adjudicated after the removal of diverse claims. By contrast, a federal court exercising original diversity jurisdiction, restricted by the complete diversity requirement of Strawbridge $v$. Curtiss, ${ }^{173}$ could not have heard incidental claims. This potential to have incidental claims heard after removal should not be understood to embody a congressional policy in 1887 that favored federal court adjudication of removed incidental claims. Indeed, by instituting additional remand provisions, Congress demonstrated its concern that removal jurisdiction not usurp the traditional role of state courts. The structure of removal jurisdiction established in 1887 reaffirmed Congress's pre-Reconstruction policy that, absent complete diversity, state law claims should be decided in state court. ${ }^{174}$

The second remand provision in the 1887 statute-mandating that a case found to be improperly removed be remanded-marks the first

${ }^{170} I d$. (emphasis added).

${ }_{171}$ This statute marks the first appearance of the provision that is currently codified at 28 U.S.C. $\S 1447$ (c) and (d):

Whenever any cause shall be removed from any State court into any circuit court of the United States, and the circuit court shall decide that the cause was improperly removed, and order the same to be remanded to the State court from whence it came, such remand shall be immediately carried into execution, and no appeal or writ of error . . . shall be allowed.

Judiciary Act of 1887,24 Stat. at 553. The prohibition of appellate review repealed $\S 5$ of the 1875 Act, which had expressly provided for review of remand orders. See supra note 156.

17224 Stat. at 553.

1737 U.S. (3 Cranch) 267, 267-68 (1806).

174 Cf. 1A J. MOORE \& B. Ringle, supra note 10, TI 0.156[1] (discussing the Judiciary Act of 1887's restriction of removal jurisdiction). 
appearance of what is now section 1447 (c). ${ }^{175}$ This provision should be interpreted in the context of a statute that limited the availability of removal. ${ }^{176}$ Congress directed that cases improperly removed be remanded in order to ensure that only cases substantially within the limited jurisdiction of federal courts could properly be removed. The provision should not be interpreted as limiting remand to cases improperly removed in order to preserve a defendant's right to have properly removed incidental claims adjudicated in federal court. Indeed, a district judge confronted with a properly removed case under the 1887 Act that, after federal law claims had been dismissed, contained only incidental claims might well have decided that the case had become "improperly removed."177 Nothing would have restrained the judge from remanding such a case. Under the 1887 Act, ${ }^{178}$ unlike the 1875 Act, ${ }^{178}$ the remand order would have been unreviewable, either by appeal or extraordinary writ. $^{180}$

178 See supra note 171 for the text of the 1887 Act.

${ }^{176}$ In Shamrock Oil \& Gas Corp. v. Sheets, 313 U.S. 100 (1941), the Supreme Court analyzed the implications of the revision of the 1875 Act by the 1887 Act. It concluded:

Not only does the language of the Act of 1887 evidence the Congressional purpose to restrict the jurisdiction of the federal courts on removal, but the policy of the successive acts of Congress regulating the jurisdiction of federal courts is one calling for the strict construction of such legislation. The power reserved to the states under the Constitution to provide for the determination of controversies in their courts, may be restricted only by the action of Congress in conformity to the Judiciary Articles of the Constitution. "Due regard for the rightful independence of state governments, which should actuate federal courts, requires that they scrupulously confine their own jurisdiction to the precise limits which the statute has defined."

Id. at 108-09 (citations omitted).

177 There is a similar modern response to the conclusion that $\$ 1447(\mathrm{c})$ forbids the remand of any properly removed case. Rule 15(c) of the Federal Rules of Civil Procedure provides for the relation back of amendments to the time of the pleading. An amendment deleting all federal claims would arise out of the "conduct, transaction, or occurrence" set forth in the original pleading. FED. R. Grv. P. 15(c). As a result of the legal fiction of an amendment relating back to the pleadings, no federal claims would appear on the face of the pleading at the time of removal. The removal to federal court would thus have been "without jurisdiction," $\S 1447(\mathrm{c})$, and the court would be obliged to remand the case. See id.

A rejoinder to this argument, albeit a formalistic one, is to point to 28 U.S.G. \$ 1446(d) (1982), under which the defendant might then be liable to "pay all costs and disbursements incurred by reason of the removal proceedings should it be determined that the case was not removable or was improperly removed."

${ }_{178}$ See supra note 171 for the relevant text of the 1887 Act.

170 See supra note 156 for the relevant text of the 1875 Act.

180 In United States v. Rice, 327 U.S. 742 (1946), the Supreme Court stated:

Congress, by the adoption of these provisions, . . . established the policy of not permitting interruption of the litigation of the merits of a removed cause by prolonged litigation of questions of jurisdiction of the district 
Ultimately, the most probative evidence of the intended scope of section $1447(\mathrm{c})$ is found in the history of section 1441 (c).$^{181}$ In defining federal jurisdiction over incidental claims in the diversity context, Congress has consistently stated that a federal court, in its discretion, may remand incidental state law claims. This discretion was provided even in 1875, when Congress implemented the broadest federal jurisdictional scheme in history. ${ }^{\mathbf{1 8 2}} \mathrm{Had}$ Congress ever addressed the problem of federal question jurisdiction and incidental claims in the removal context, section 1441(c) strongly suggests that Congress would have similarly provided district courts the power to remand, in their discretion, state law claims incidental to federal questions.

\section{A Federal Court's Common Law Authority Includes THE POWER to REMAND}

The Supreme Court, ruling on a petition for mandamus, will decide whether a federal court has power to remand a properly removed case that in its present posture contains only incidental claims. In so ruling, this Comment argues that the Court will determine whether section $1447(c)^{\mathbf{1 8 3}}$ limits the exercise of common law jurisdiction over incidental claims removed from state court. ${ }^{184}$ This Part first examines the posture in which this issue is presented and the significance of it being decided on a petition for mandamus. It concludes that, because section 1447(c) does not govern the remand of incidental claims, the extraordinary remedy of mandamus should not lie to compel a district court to exercise its remand power by the terms of the statute. It then looks to some issues involved in exercising judicial discretion over incidental claims in the removal context.

court to which the cause is removed. This was accomplished by denying any form of review of an order of remand ....

Id. at 751 .

181 See supra note 12 for the text of $\S 1441$ (c).

182 See supra note 156 and accompanying text; see also supra notes 153-59 and accompanying text (discussing the breadth of the Judiciary Act of 1875).

18328 U.S.C. § 1447(c) (1982).

184 This Comment argues that the petition for mandamus at issue in CarnegieMellon Univ. v. Cohill, No. 85-3619, slip op., 41 Fair Empl. Prac. Cas. (BNA) 1046 (3d Cir. Aug. 29, 1986), granting mandamus in Boyle v. Carnegie-Mellon Univ., 648 F. Supp. 1318 (W.D. Pa. 1985), vacated and reh'g granted, No. 85-3619, slip op., 41 Fair Empl. Prac. Cas. (BNA) 1888 (3d Cir. Sept. 24, 1986), affd by an equally divided court, No. 85-3619, slip op. (3d Cir. Nov. 13, 1986) (en banc), cert. granted, 107 S. Ct. 1283 (1987), discussed supra note 14, will be decided in line with United Mine Workers v. Gibbs, 383 U.S. 715 (1966), Aldinger v. Howard, 427 U.S. 1 (1976), and Owen Equip. \& Erection Co. v. Kroger, 437 U.S. 365 (1978). See supra notes 4069 and accompanying text for a discussion of these cases. 


\section{A. Reviewing a Remand Order on a Petition for Mandamus}

Before Thermtron Products, Inc. v. Hermansdorfer, ${ }^{185}$ review of remand orders, either by appeal or extraordinary writ, had been thought to be forbidden under section 1447 (d). ${ }^{186}$ In Thermtron, however, the Court reasoned that mandamus was not barred because sections 1447 (c) and 1447(d) were to be construed together. ${ }^{187}$ Thus, the prohibition of appellate review in section 1447(d) operates only when the stated reason for remand is that the case was "removed improvidently and without jurisdiction."188 Because the district judge in Thermtron remanded for reasons not stated in section 1447(c), the bar of section 1447(d) had no effect. ${ }^{189}$ Mandamus would lie "to prevent nullification of the removal statutes by remand orders resting on grounds having no warrant in the law."180

To those who view the jurisdictional authority of lower federal courts as based strictly on statute, the Thermtron Court's interpretation of section 1447(c) expanded the scope of a federal court's duty under the removal and remand statutes. Because proper removal under section $1441(b)^{191}$ vests jurisdiction over both the federal and incidental claims of a case, they reason, section 1447(c) controls the disposition of a properly removed case's incidental claims. Discretionary remand, even of a case that contains only an incidental claim, violates section 1447(c). Mandamus, therefore, should compel the district court to vacate its remand order. This reasoning not only confuses statutorily-defined jurisdiction with a court's residual power under article III to dispose of incidental claims, but it also fails to account for the traditional standard for granting petitions for mandamus and the extraordinary reasons why that standard was met in Thermtron.

185423 U.S. 336 (1976).

188 "An order remanding a case to the State court from which it was removed is not reviewable on appeal or otherwise . . ." 28 U.S.C. § 1447(d) (1982); see supra note 180 and accompanying text.

187 See Thermtron, 423 U.S. at 345.

18828 U.S.C. § 1447(c) (1982).

189 See Thermtron, 423 U.S. at 351.

180 Id. at 353. Justice Rehnquist, in dissent, argued that this interpretation was at odds with Congress's purpose:

If anything is clear from the history of the prohibition against review, it is that Congress decided that potential errors in individual cases did not justify permitting litigants to challenge remand orders. To carry out its policy of avoiding further interruption of the litigation of removed causes, properly begun in state courts, Congress decided to place final responsibility for implementation of its removal scheme with the district courts. It is not for this Court to strike that balance anew.

Id. at 360-61 (Rehnquist, J., dissenting) (citation omitted).

19128 U.S.C. \& $1441(\mathrm{~b})$ (1982). 


\section{The Standard for Granting a Writ of Mandamus}

Traditionally, the writ of mandamus has been used in the federal courts "to confine an inferior court to a lawful exercise of its prescribed jurisdiction or to compel it to exercise its authority when it is its duty to do so." 192 Mandamus is granted only in extraordinary situations. The Supreme Court has stated that "only exceptional circumstances amounting to a judicial 'usurpation of power' will justify the invocation of this extraordinary remedy."18s The writ, for example, has been invoked when a district judge abused his discretion under the Federal Rules of Civil Procedure by repeatedly referring cases to a master improperly. ${ }^{194}$ Finally, the party seeking mandamus has "the burden of showing that its right to issuance of the writ is "clear and indisputable." "185

\section{Applying the Standard to Remand Orders}

In Thermtron, the statutory requirements for subject matter jurisdiction had been met: the parties were citizens of different states, and the claim exceeded $\$ 10,000$. The district judge had no authority to consider whether, because of his crowded docket, state court would be a better forum for the case. Nor could the judge claim that his reason for remanding was within the court's residual power to fashion common law exceptions. ${ }^{198}$ The district judge's order to remand exceeded the

192 Roche v. Evaporated Milk Ass'n, 319 U.S. 21, 26 (1943). Because an order remanding a removed action does not represent a final judgment reviewable on appeal, " " $t$ ] he remedy in such a case is by mandamus to compel action, and not by writ of error to review what has been done." "Thermtron, 423 U.S. at 353 (quoting Railroad Co. v. Wiswall, 90 U.S. (23 Wall.) 507, 508 (1874)). Under the All Writs Act "[t]he Supreme Court and all courts established by Act of Congress may issue all writs necessary or appropriate in aid of their respective jurisdictions and agreeable to the usages and principles of law." 28 U.S.C. § 1651(a) (1982). In In re Winn, 213 U.S. 458 (1909), the Supreme Court responded to an argument "that mandamus will not lie to control the judgment or judicial discretion of the court to which the writ is proposed to be directed" by stating that the assertion was "true where the judgment or judicial discretion is within the limits of jurisdiction, but not otherwise." Id. at 467-68.

${ }_{183}$ Will v. United States, 389 U.S. 90, 95 (1967) (citing De Beers Consol. Mines, Ltd. v. United States, 325 U.S. 212, 217 (1945)); see also Ex parte Fahey, 332 U.S. 258,259 (1947) (the nature of the mandamus remedy is "drastic and extraordinary").

194 See La Buy v. Howes Leather Co., 352 U.S. 249, 256 (1957). Likewise, in Thermtron, there was evidence that the district judge had repeatedly remanded diversity cases properly removed to his court. Thermtron, 423 U.S. at 341 n.4.

185 Bankers Life \& Casualty Co. v. Holland, 346 U.S. 379, 384 (1953) (quoting United States v. Duell, 172 U.S. 576, 582 (1899)).

${ }^{186}$ But cf. Colorado River Conservation Dist. v. United States, 424 U.S. 800, 817 (1976) (fashioning a common law exception to the duty to exercise statutorily-conferred jurisdiction by permitting abstention for reasons of " " $w]$ ise judicial administration, giving regard to conservation of judicial resources and comprehensive disposition of litiga- 
court's statutorily-defined power. The defendant's right to have a federal court adjudicate the case after removal was "clear and indisputable." Mandamus was an appropriate remedy to enforce this right.

Properly removed incidental claims present an altogether different situation. Even if one subscribes to the broad interpretation of Thermtron and concludes that the remand of any properly removed case violates a strict reading of section 1447 (c), it is questionable whether the remand of a case that contains only an incidental claim gives rise to a "judicial 'usurpation of power." "187 The duty of a federal court to exercise jurisdiction over such a case should hardly be considered "clear and indisputable." Absent diversity of citizenship, a federal court should have virtually no interest in a case that contains only a state law claim. ${ }^{188}$ But the petition for mandamus in this situation should be denied, however, not only because of the extraordinary nature of the remedy. Mandamus should not lie because a judge's discretionary remand of an incidental claim does not violate section 1447(c).

Only if Congress intended section 1447(c) to forbid the remand of any case properly within a court's removal jurisdiction would the remand of a properly removed case that in its present posture contains only an incidental claim would violate the statute. Although this interpretation can be inferred from the provision that cases "without jurisdiction" shall be remanded, the history of removal jurisdiction indicates that the only cases that Congress intended to protect from remand were those that fell within the federal courts' limited statutory jurisdiction. Any claimed right to have an incidental claim adjudicated after removal is untenable. Moreover, evidence of the scope that Congress intended section 1447 (c) to have is its treatment of incidental claims "seperable" from federally cognizable claims under the predecessors of section 1441(c). Under these provisions, a federal court, in the exercise of its discretion, could remand the incidental claims of a properly removed case. Finally, Congress first enacted the predecessor to section 1447(c) as part of a statute the purpose of which was to limit the removal jurisdiction of federal courts. It strains the imagination to conclude that

tion." " (quoting Kerotest Mfg. Co. v. C-O-Two Fire Equip. Co., 342 U.S. 180, 183 (1952))).

${ }_{107}$ See Will, 389 U.S. at 95 (quoting De Beers, 325 U.S. at 217).

188 If, after removal, an incidental state law claim has remained pending for a long time before the court dismisses all federal law claims, the court may have some interest in deciding the state law claim, especially if the statute of limitations has run on that claim. See infra notes 203-06 and accompanying text. A court might also have interest in deciding a case in which, after the defendant has removed, the plaintiff, attempting to defeat the defendant's right to a federal forum, has amended her complaint to delete all federal law claims. See infra notes 207-08 and accompanying text. 
Congress in 1887 implicitly intended the new remand provision of a jurisdictional statute, which otherwise limited the availability of the federal courts, to protect a properly removed indicental claim from remand. Section 1447(c) should not be interpreted to govern a court's power to remand incidental claims.

An order remanding a properly removed incidental claim, like the order in Thermtron, is made for reasons not stated in section 1447(c). Appellate review of such an order, therefore, is not barred by section 1447(d). An order remanding incidental claims, however, in contrast to the order in Thermtron, rests on legitimate grounds. Mandamus was appropriate in Thermtron because the judge had no authority to consider his crowded docket in deciding whether to remand. But because section 1447(c) does not " 'expressly or by implication negate[]' the exercise of jurisdiction over the nonfederal claim,"198 under the authority defined in United Mine Workers $v$. Gibbs, ${ }^{200}$ the court can exercise its incidental jurisdiction and, in its discretion, remand a properly removed case that contains only an incidental claim.

B. The Justifications for Incidental Jurisdiction Support Discretionary Remand of Incidental Claims in Certain Cases

Gibbs identifies when a federal court may properly exercise its common law power under article III to adjudicate state law claims. "[C]onsiderations of judicial economy, convenience, and fairness to litigants" justify a federal court's incidental jurisdiction over state law claims. ${ }^{201}$ The first two factors relate to the exercise of incidental jurisdiction in the removal context as much as they relate to incidental jurisdiction in other contexts. Incidental jurisdiction saves the collective judicial resources of state and federal court systems from duplicative litigation. ${ }^{202}$ A federal court's power to hear incidental claims in any jurisdictional setting ensures that litigants will not be dissuaded from pursuing federal law claims in federal court solely because a state court's general jurisdiction empowers it to hear state and federal claims together. Without incidental jurisdiction, the usefulness of the Federal Rules of Civil Procedure's liberal joinder provisions would be undercut. $^{203}$

198 Owen Equip. \& Erection Co. v. Kroger, 437 U.S. 365, 377 (1977) (quoting Aldinger v. Howard, 427 U.S. 1, 18 (1976).

200383 U.S. 715 (1966).

201 Id. at 726.

${ }^{202}$ See Note, The Evolution and Scope of the Doctrine of Pendent Jurisdiction in the Federal Courts, 62 Colum. L. REv. 1018, 1044 (1962).

${ }^{203}$ See Jurisdiction Primer, supra note 9, at 111. 
A federal court exercising removal jurisdiction, however, must give special consideration to the third justification for incidental jurisdiction-fairness to litigants. Removal jurisdiction raises difficult issues of fairness that concern both plaintiffs and defendants.

\section{Fairness to Plaintiffs: State Statutes of Limitations}

When a federal court exercising original jurisdiction decides not hear an incidental claim, Gibbs instructs the court to dismiss the claim without prejudice. ${ }^{204}$ Fairness to the plaintiff dictates that she be afforded a chance to relitigate the claim in state court. A federal court can be no more fair to such a plaintiff. When a plaintiff brings an action that contains both state law and federal law claims against the defendant, she controls the choice of forum. She bears the risk that the federal court will find her federal law claims to be insubstantial and dismiss the case. She also bears the risk that, after dismissal; the state law claims will be time barred in state court.

Considerations of fairness to the plaintiff are different when a federal court exercises removal jurisdiction. Here, the plaintiff has chosen to pursue her federal law and state law claims in state court. Once she pleads a federal law claim, she does not control whether the case will be litigated in federal court since the defendant will have the right to remove. If the defendant chooses to remove, it is possible, if not likely, that the case will remain pending in federal court after the statute of limitations for bringing the state law claim in state court has passed. ${ }^{205}$ Assume that after removal the federal court dismisses the federal law claim and, exercising its discretion under Gibbs, decides not to hear the state law claim. A federal court without power to remand would dismiss the case without prejudice. If the plaintiff is from a state without a "saving statute,"

204 See Gibbs, 383 U.S. at 726-27.

${ }^{208}$ See Carnegie-Mellon Univ. v. Cohill, No. 85-3619, slip op. at 19, 41 Fair Empl. Prac. Cas. (BNA) 1046, 1053 (3d Cir. Aug. 29, 1986) (Stapleton, J., dissenting) ("Removed cases frequently remain pending in the federal court well past the limitations deadline."), granting mandamus in Boyle v. Carnegie-Mellon Univ., 648 F. Supp. 1318 (W.D. Pa. 1985), vacated and reh'g granted, No. 85-3619, slip op., 41 Fair Empl. Prac. Cas. (BNA) 1888 (3d Cir. Sept. 24, 1986), aff'd by an equally divided court, No. 85-3619, slip op. (3d Cir. Nov. 13, 1986) (en banc), cert. granted, 107 S. Ct. 1283 (1987).

${ }^{206}$ See Cohill, slip op. at 19-20, 41 Fair Empl. Prac. Cas. (BNA) at 1053. Judge Stapleton referred to state savings statutes, but did not cite any.

Pennsylvania has a "saving statute" that would probably apply to the state law claims of plaintiffs in Cohill. The state law claims are described supra note 14. The statute provides in pertinent part:

If a civil action or proceeding is timely commenced and is terminated, a 
heard in any forum. Because the defendant controls access to federal court, this bar to relief seems more unfair than when the plaintiff initially chooses a federal forum for her case. Federal court power to remand in this situation would avoid this unfairness. After remand, irrespective of the state's statute of limitations, the state court would be able to hear the state law claim. ${ }^{20 z}$

\section{Fairness to Defendants: Avoiding Manipulation}

A federal court that considers fairness to the defendant will not always remand incidental claims after it dismisses all federal law claims. The rule in Gibbs that, after federal law claims are dismissed, incidental claims should "[c]ertainly" be dismissed as well, ${ }^{208}$ should be somewhat modified in the context of removal jurisdiction. With removal, Congress has given a defendant the right to litigate her federal law claim in federal court. After defendant has invoked her right to remove, and the district court has exercised its discretion to hear the case's incidental claims, the court should be more willing to decide incidental claims than it would be in its original jurisdiction. A plaintiff should not be permitted to jockey the defendant back and forth between state and federal courts by deleting her federal law claims and moving

party . . may . . commence a new action or proceeding upon the same cause of action within one year after the termination and any other party may interpose any defense or claim which might have been interposed in the original action or proceeding.

42 Pa. Cons. Stat. ANN. § 5535(a)(1) (Purdon 1981). In Deats v. Commercial Credit Plan Consumer Discount Co., 83 Lackawanna Jurist 221 (1982), plaintiff brought suit in state court after a timely federal suit had been dismissed without prejudice for lack of jurisdiction. The Court of Common Pleas of Lackawanna County, Pennsylvania, interpreted the statute to allow "a plaintiff a one year period of time within which to recommence his suit in certain proceedings after a dismissal on grounds other than the merits of the case." Id. at 223. It stated further that "[i]t is the general rule that to fall within the scope of a saving statute, the second action must be based substantially on the same cause of action and must involve substantially the same parties." Id. The court held that, "although the federal and state causes of action arise out of the same transaction, the defendants in the two actions are entirely different," $i d$. , and, therefore, the statute did not apply. It appears, then, that the statute would apply when a timely federal suit had been dismissed without prejudice and, within one year, the plaintiff brought suit in state court against the same defendants for a claim arising out of the same transaction.

${ }_{207}$ See 28 U.S.C. $\$ 1447$ (c) (1982) (after remand, "[t]he State court may . . . proceed with [the] case.") Moreover, even if the statute of limitations does not bar the plaintiff's claim, she deserves the surer-footed reading of state law available in state court, especially when the state claim involves unsettled areas of state law. See Naylor v. Case and McGrath, Inc., 585 F.2d 557, 563-64 (1978) (exercising abstention through remand because the state statute at issue had not been construed by the state court of last resort).

${ }^{208}$ Gibbs, 383 U.S. at 726. 
for remand at strategic moments. ${ }^{209}$

\section{CONCLUSION}

Although a federal court exercising original jurisdiction ordinarily resolves the question of judicial power over an incidental claim on the pleadings, whether jurisdiction should be exercised is a question that remains open throughout the litigation. Nothing in the history of removal jurisdiction indicates, explicitly or implicitly, that Congress has ever intended a federal court to treat incidental claims differently after they are removed. In the few provisions that pertain to incidental claims, Congress has consistently stated that a federal court should exercise jurisdiction over an incidental claim in its discretion. In section 1441(c), ${ }^{210}$ Congress states that a federal court may remand a properly removed incidental claim in its discretion. Although this provision historically pertained to diversity jurisdiction and incidental claims in the removal context, it most likely indicates what Congress would have done had it addressed the question of federal question jurisdiction and incidental claims in the removal context. Moreover, when Congress first enacted general federal question jurisdiction in $1875^{211}$-a statute that conferred the broadest federal jurisdiction in history-the removal provision directed that the propriety of federal jurisdiction was to be considered throughout the pendency of the suit, not just at the time of removal. When in $1887^{212}$ Congress provided that claims "without ju-

${ }^{209}$ Cohill presents this issue. After defendants removed, there was extensive discovery, twice extended at plaintiff's request. Only then did plaintiffs discover that their federal law claim was legally defective and moved to remand. See Petition for Writ of Mandamus at 4-5, Cohill, No. 85-3619, slip op., 41 Fair Empl. Prac. Cas. (BNA) 1046 (3d Cir. Aug. 29, 1986). Defendants have suggested that the amendment was sought because the case was ripe for summary judgment or trial. See Cohill, slip op. at 14, 41 Fair Empl. Prac. Cas. (BNA) at 1051.

A number of decisions recognize the unfairness of permitting a plaintiff to defeat a defendant's right to a federal forum. See Westmoreland Hosp. Ass'n v. Blue Cross, 605 F.2d 119, 123 (3d Cir. 1979) ("[a] subsequent amendment to the complaint after removal designed to eliminate the federal claim will not defeat federal jurisdiction), cert. denied, 444.U.S. 1077 (1980); In re Greyhound Lines, Inc., 598 F.2d 883, 884 \& n.1 (5th Cir. 1979) ("plaintiff cannot precipitate a remand of the action by amending complaint to eliminate federal claim," especially when the plaintiff's actions are motivated by voluntary tactical decisions); see also Barrett v. McDonald's, 419 F. Supp. 792, 793 (W.D. Okla. 1976) ("Once a case has been properly removed a Plaintiff cannot successfully do anything to defeat federal jurisdiction and force a remand"); Jacks v. Torrington Co., 256 F. Supp. 282, 287 (D.S.C. 1966) ("the continued jurisdiction of a federal court after proper removal will not be allowed to be determined at the whim and caprice of the plaintiff by manipulation of the Complaint by amendment").

${ }^{210} 28$ U.S.C. $\$ 1441$ (c) (1982).

21 Judiciary Act of 1875 , ch. 137,18 Stat. 470.

212 Judiciary Act of 1887 , ch. 373, 24 Stat. 522. 
risdiction" shall be remanded, Congress was concerned only with protecting the limited federal subject matter jurisdiction defined by statute. Understood in this context, section $1447(\mathrm{c})^{213}$ should not be interpreted to limit a federal court's power to dispose of incidental claims.

Because the statute does not limit a federal court's incidental jurisdiction, a court has common law power to remand. A court that exercises this power by remanding a case that in its present posture contains only a properly removed incidental claim does not violate the separation of powers under the constitution. Common law remand does not constitute impermissible lawmaking by the judiciary. Although without jurisdictional statutes a lower federal court is powerless to hear cases, once Congress has conferred jurisdiction, a court has residual power under article III to define the scope of a case that the statute empowers it to hear. Just as the federal court in its original jurisdiction has power to dismiss an incidental claim, in its removal jurisdiction it has power to remand. How the power to remand an incidental claim is exercised should depend on the equities of each case, a determination properly left to the discretion of the court. 